CAMP Working Paper Series

No $5 / 2013$

\title{
Local Natural Resource Curse?
}

Lars Erik Borge, Pernille Parmer and Ragnar Torvik

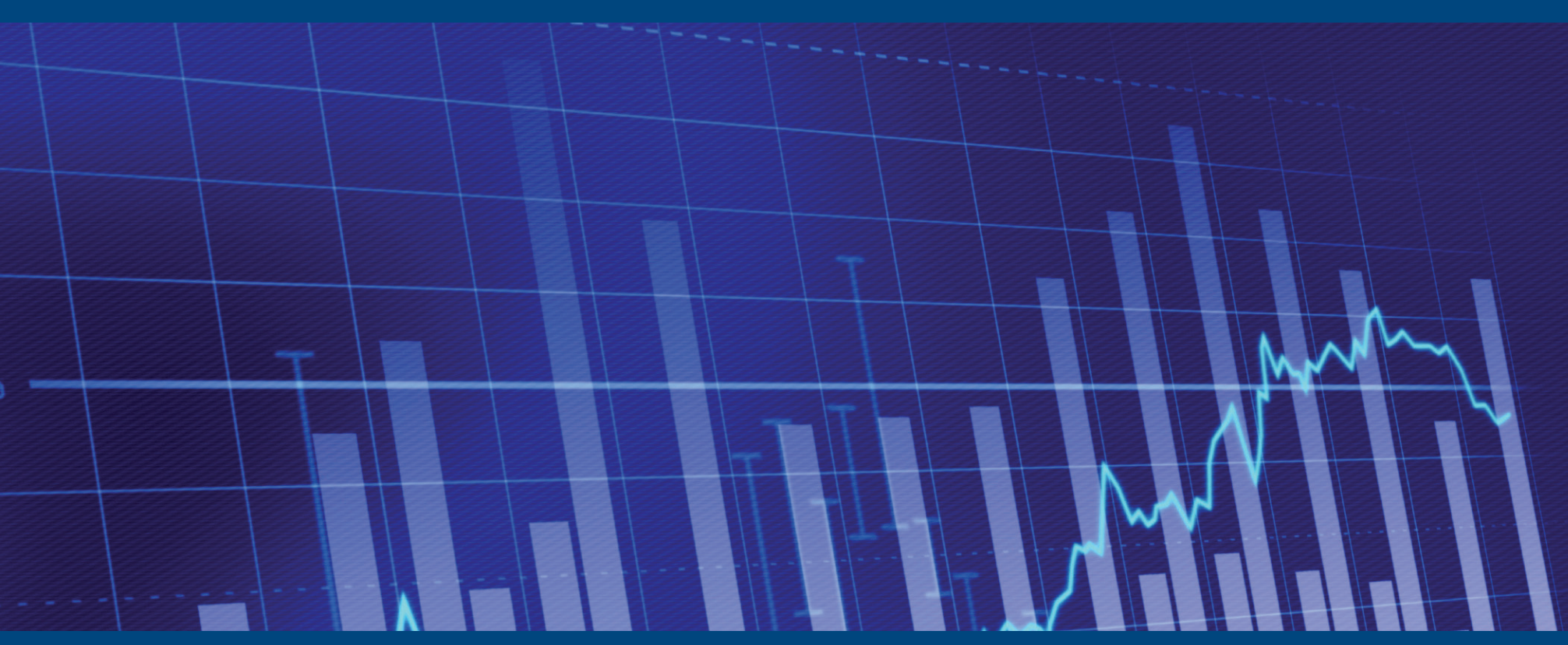

(c) Authors 2013.

This paper can be downloaded without charge from the CAMP website http://www.bi.no/camp 


\title{
Local Natural Resource Curse?*
}

\author{
Lars-Erik Borge $^{\dagger} \quad$ Pernille Parmer $^{\ddagger} \quad$ Ragnar Torvik $^{\S}$
}

June 19, 2013

\begin{abstract}
The large variation in revenues among Norwegian local governments can partly be explained by revenues collected from hydropower production. This revenue variation, combined with good data availability, can be used to extend the literature on the resource curse in two directions. First, to ensure that there is no problem of endogeneity in the analysis we obtain a purely exogenous measure of local revenue by instrumenting the variation in hydropower revenue, and thus total revenue, by topology, average precipitation and meters of river in steep terrain. Second, using data for revenue derived from hydropower production in Norwegian local governments we test the 'Rentier State' hypothesis; that revenue derived from natural resources should harm efficiency more than revenue derived from other sources such as taxation. Although we do find that higher local government revenue reduces the efficiency in production of public goods, we do not find that this effect is stronger for natural resource revenue than for other revenue.

Keywords: resource curse, rentier state, identification, local government, political economy.

JEL: D78, H11, H27, H71, H72, H75, Q2

${ }^{*}$ We are grateful for comments and suggestions from Roland Hodler, Andreas Kotsadam, Päivi Lujala, Bjarne Strøm, and seminar participants at Harvard, University of Oslo, IIPF Dresden, as well as our own university. We are also grateful for the time consuming data collection help from Ole Einar Tveito at The Norwegian Meteorological Institute.

${ }^{\dagger}$ Norwegian University of Science and Technology, Department of Economics, Dragvoll, N-7491 Trondheim, Norway; E-mail: lars.erik.borge@svt.ntnu.no

$\ddagger$ Norwegian University of Science and Technology, Department of Economics, Dragvoll, N-7491 Trondheim, Norway; E-mail: parmer@svt.ntnu.no

$\S$ BI Norwegian Business School, and Norwegian University of Science and Technology, Department of Economics, Dragvoll, N-7491 Trondheim, Norway; E-mail: ragnar.torvik@svt.ntnu.no
\end{abstract}




\section{Introduction}

A number of studies within the so-called 'resource curse' literature argue that public revenue derived from natural resources has perverse effects for economic efficiency. Several theories have been put forward to explain why this could be the case, and a large number of empirical papers investigate the potential mapping from resource abundance to poor economic performance. In this paper, by using data for revenue from hydro-electrical power plants in Norwegian local governments, we aim to extend this literature in two directions. First, by using geographical characteristics such as meters of river, steepness of terrain and average precipitation as instruments, we arrive at a measure of public revenue which is exogenous. This allows us to test what we term the "Paradox of Plenty" hypothesis; that high public revenues retards economic efficiency. Second, our data also allows us to investigate what we term "the Rentier State" hypothesis; that the efficiency effect of natural resource abundance is different from the efficiency effect of other types of public revenue such as taxation. We find that there is support for a claim that higher revenue retards efficiency, but do not find support for the claim that natural resource revenue damages efficiency more than revenue derived from other sources. Thus, we find support for "the Paradox of Plenty" hypothesis, but not for "the Rentier State" hypothesis.

The first known example of the resource curse is probably the effect of silver and gold from the American colonies on the Spanish state. According to North and Thomas (1973) these revenues freed the state from the constraints of the parliament, leading to a concentration of political power that is partly to blame for the economic decline of Spain in the seventeenth century. North and Thomas's example is closely linked to the theories of the 'rentier state', a term first used by Mahdavy (1979). The rentier state hypothesis asserts that when resource abundance makes public revenue less dependent on taxation, citizens monitoring of politicians becomes weaker, and policies worse. Although intuitively appealing and popular, it seems fair to say that its theoretical foundations are not yet fully satisfactory developed. For instance, one could ask why citizens should care about the origin of public revenues, and not only about the quality and quantity of the public goods delivered. Nevertheless, given the prominent role of the rentier state hypothesis in the resource curse literature, it is a bit surprising that the large empirical literature on the resource curse does not investigate this hypothesis. Rather than studying the effect of resource revenue versus other public revenue, this literature investigates the isolated effect of resource abundance. Thus it could be argued that what this literature studies is the Paradox of Plenty hypothesis, but not the Rentier State hypothesis. It should, therefore, have some interest to expand the resource curse literature to study also the latter.

The empirical literature on the resource curse is an area of intense debate. Since its change in focus from case-studies such as Gelb (1988) and Karl (1997) to multi country regressions following Sachs and Warner (1995), the main challenges have been the possibility of omitted variables as well as the endogeneity of measures of resource abundance. To address the omitted variables problem a number of papers, such as Aslaksen (2010) and Collier and Goderis (2008), have employed panel data that allows for country or local government fixed effects. The problem of endogeneity of the resource abundance measure has been more challenging. The initial literature such as Sachs and Warner (1995) and Mehlum et al. (2006) used flow measures such as share of natural resources in exports or in GDP. As pointed out by many, such a measure is endogenous, and likely to overes- 
timate the negative effects of resource abundance. The reason for this is that countries are measured as more resource abundant when they experience a reduction in alternative exports, a lower degree of industrialization, or a reduction in physical or human capital. In short, resource intensive production may be the result of poor economic performance for reasons other than resource abundance.

One strand of recent literature, in particular Brunnschweiler and Bulte $(2008 \mathrm{a} b)$ and Alexeev and Conrad (2009), has on the basis of this employed the value of subsoil assets as a measure of resource abundance, arguing that such a stock measure is more exogenous that flow measures. This is not fully satisfactory, however, and may bias the result in the opposite direction from the initial literature. Countries that has long been industrialized may have discovered more of their subsoil assets, leading such successful countries to be measured as resource abundant. For instance, Collier $(2010)$ compares the value of known subsoil assets per square kilometer in countries with high GDP to those with low GDP. In the former countries the value of known subsoil assets is four times the value in the latter. He argues that the rich and developed countries simply has had more time to discover their resources, and thus even if more has been extracted, their measured resource wealth is higher.

Partly on this background, researchers have recently increased their attention towards finding more exogenous measures of resource abundance. Tsui (2011) use initial oil endowments to instrument for oil discoveries. Monteiro and Ferraz (2010) use a geographic rule that determines the share of oil revenues that accrue to different Brazilian local governments. Caselli and Michaels (2011) use municipal oil output to instrument for municipal revenues in Brazil.

We complement these studies by extending the resource curse literature to allow for a purely exogenous measure of revenue generated from hydropower production in Norwegian local governments. Norway has the highest per capita production of hydropower in the world, and about 98 percent of total electricity use is hydropower. With 430 local governments, huge differences in public sector revenue from the hydropower sector, and a close mapping from geographical characteristics to these revenues, local governments in Norway should be a promising candidate in the search for true exogenous variation in total revenues and resource abundance. By utilizing variation in topology, average precipitation and meters of river in steep terrain, the revenue measure do not depend on economic decisions. Thus like the initial literature we use a flow measure of resource abundance, but we avoid the potential overestimation of negative effects of resource income.

Our paper is also related to the growing literature that uses geographical characteristics in economic analyses. Although this literature does not investigate the resource curse, it shares with us the use of geography in constructing instruments. Duflo and Pande (2007) use the river gradient as instrumental variable to study the productivity and distributional effects of large irrigation dams in India, and investigate how dams affect welfare in affected districts. A comparison of outcomes in regions with and without dams is unlikely to provide casual estimates. Regions with relatively more dams are likely to differ in other dimensions, as for example potential agricultural productivity. Their idea is that the river gradient affects districts suitability for dams, and they find positive effects in districts located downstream from a dam, but negative effects in districts where the dam is located.

Another study by Lipscomb et al. (2011) studies development effects of electrification between 1960 and 2000 using geological placement of hydropower plants in Brazil. Elec- 
trification is most probably correlated with unobservable effects like political decisions and other demand side concerns. They address this potential problem by isolating the portion of variation in electricity grid expansions attributed to "exogenous" engineering cost considerations. Hydropower plant placement is predicted based on geological characteristics like river gradient, water flow, and distance to the Amazon. Their results indicate a positive effect of electricity on some aspects of productivity.

Rural electrification has also been studied by Dinkelman (2010). She estimates the impacts of electrification on employment growth in South Africa. To identify the causal effect of electrification, land gradient is used as instrumental variable for project placement, generating exogenous variation in electricity project allocation. The empirical analysis shows significant effect on employment, indicating that studies that ignore employment effects could be missing important economic impacts if the infrastructure has a home production bias.

Natvik et al. (2011) investigate the causal effect of election stakes on turnout via an instrumental variable approach. Their empirical design exploit that topography determines hydropower income by using variables capturing variations in altitude across local governments.

None of these papers develop an instrument such as ours, nor distinguish between the Paradox of Plenty hypothesis and the Rentier State hypothesis.

The rest of the paper is organized as follows. In Section 2 we discuss relevant institutional characteristics of the Norwegian local governments and hydropower revenue, while in Section 3 there is a short description of the data. Section 4 discusses the empirical specification, our identification strategy, and the hypotheses. The results are summarized in Section 5, before robustness regressions are discussed in Section 6. Concluding remarks are offered in Section 7. Appendix A through J contains more detailed information that we refer to in the main text.

\section{The Norwegian local governments}

\subsection{Financing and responsibilities}

In Norway, as in the other Scandinavian countries, local governments are important providers of welfare services. The local governments are responsible for child care, primary and lower secondary education (1st to 10th grade), care for the elderly (nursing homes and home based care), primary health care (general practitioners, health centers, and emergency ward), and social services (mainly social assistance and child custody). The welfare services amount to $3 / 4$ of the total budget and are regulated and based on national law. Important welfare services provided by higher level governments are upper secondary education (county responsibility) and hospitals (state responsibility). Many additional activities are also provided by the local governments, although they make up a small share of the budget. They can broadly be categorized as culture (libraries, cinemas, sports facilities, etc), infrastructure (roads, water, sewage, and garbage collection), industry, and housing. The local governments are administered by a directly elected municipal council, ruled by a mayor and an executive board. Local elections are held every fourth year. This way the local governments are partly local organizations with demo- 
cratic institutions, and partly agents of the central government in the provision of welfare services.

The local governments are largely financed by a combination of local taxes and central government grants, and total revenues made up for 16 percent of GDP mainland in $2007 \sqrt[1]{1}$ During the period under study $\left.\right|^{2}$ taxes amounted to approximately 45 percent of total revenues and grants to a bit more than 35 percent. User charges and other revenues accounted for the rest. The local governments collect income and wealth tax from individuals, property tax (residential and commercial property), and natural resource tax from power companies (see below). Most taxes are of the revenue sharing type where the local tax rates are determined by the central government. In practice, tax discretion is restricted to the property tax and some other relatively small taxes. The grant system consists of earmarked grants and general purpose grants. There is a large number of earmarked grants for specific purposes, but the general purpose grants are most important for the distribution of revenues. The main role of the general purpose grant scheme is to equalize the economic opportunities across local governments by tax and spending need equalization. The general purpose grant scheme also includes grants to promote regional policy goals.

The system of financing implies that three types of local governments end up with high levels of fiscal capacity; small rural local governments with substantial tax revenue from hydroelectric power plants, small rural local governments that receive regional policy grants, and urban local governments with high levels of income and wealth taxes. We concentrate on the revenue variation due to differences in revenue from hydropower production. Revenues related to hydropower make up a small share of aggregate revenues, but is of high importance for individual local governments. As can be seen in Appendix A the top local governments on the revenue ranking list have significant hydropower revenues. Common to these local governments is that the hydropower revenue accounts for about half or more of their total revenue. The table also show that, on average, a local government with hydropower revenue has higher total revenue per capita. The average total revenue among local governments with hydropower revenue was NOK 32.600 in 2007. In comparison the same number for all other local governments was NOK 28.300 3 See Appendixs $\mathrm{B}$ for a more detailed description of the hydropower sector in the local governments.

Table 1 shows how the revenues are distributed among all the local governments. It is clear that local governments with a high share of hydropower revenue is in the upper total revenue per capita quantile. This shows that revenues from hydropower production relax the economic constraints for some of the local governments. In the following we describe the different sources of hydropower revenue.

\subsection{Revenues from hydropower}

Hydropower revenues are mainly collected from three sources; property tax from hydropower plants, natural resource tax and revenues from concession power. First, local governments receive property tax from power plants mainly determined by the national

\footnotetext{
${ }^{1}$ GDP mainland: Excludes petroleum production and shipping.

${ }^{2}$ The efficiency measure we use exist for the period 2001-2007 only.

${ }^{3} 1$ NOK equals about 0.2 USD.
} 
Table 1: Distribution of hydropower revenues (per capita) in local governments (2007)

\begin{tabular}{lccccccc}
\hline $\begin{array}{l}\text { Total } \\
\text { revenue } \\
\text { quartile }\end{array}$ & $\begin{array}{c}\text { Total } \\
\text { revenue*a }\end{array}$ & $\begin{array}{c}\text { Hydro } \\
\text { revenue*b } \\
\text { (mean) }\end{array}$ & $\begin{array}{c}\text { Share } \\
\text { Hydro } \\
\text { (of total) }\end{array}$ & $\begin{array}{c}\text { Share } \\
\text { Prop.tax } \\
\text { (of Hydro) }\end{array}$ & $\begin{array}{c}\text { Share } \\
\text { Nat.tax } \\
\text { (of Hydro) }\end{array}$ & $\begin{array}{c}\text { Share } \\
\text { Conc.pow } \\
\text { (of Hydro) }\end{array}$ & $\begin{array}{c}\text { Local } \\
\text { gov. } \\
\text { Hydro }>\mathbf{0}^{c}\end{array}$ \\
\hline First & $23.45-25.83$ & 0,03 & $0 \%$ & $82 \%$ & $6 \%$ & $14 \%$ & $26 \%$ \\
Second & $25.83-28.15$ & 0,25 & $1 \%$ & $67 \%$ & $8 \%$ & $25 \%$ & $51 \%$ \\
Third & $28.15-32.04$ & 0,99 & $3 \%$ & $64 \%$ & $10 \%$ & $26 \%$ & $55 \%$ \\
Fourth & $32.04-108.6$ & 7,33 & $15 \%$ & $56 \%$ & $20 \%$ & $24 \%$ & $68 \%$ \\
$95 \%-100 \%$ & $44.31-108.6$ & 21,89 & $35 \%$ & $55 \%$ & $29 \%$ & $16 \%$ & $86 \%$
\end{tabular}

ALL

\begin{tabular}{lccccccc}
\hline Mean & 30,44 & 2,15 & $5 \%$ & $65 \%$ & $12 \%$ & $23 \%$ & $50 \%$ \\
Min & 23,45 & 0 & $0 \%$ & $0 \%$ & $0 \%$ & $0 \%$ & - \\
Max & 108,59 & 58,47 & $67 \%$ & $100 \%$ & $100 \%$ & $100 \%$ & - \\
\hline
\end{tabular}

All variables are "deflated" by a cost index and corrected for payrolls taxes.

Hydro: Hydropower revenues

*) 1000 NOK (200 USD), per capita.

a) Total revenue $=$ Block grants + revenue tax + wealth tax + property tax + natural resource tax + concession power revenue

b) Hydro revenue=property tax from hydropower plants+natural resource tax+concession power revenue.

c) Share of all local governments with revenue from the hydropower sector in a given quartile.

assessment system. Second, the natural resource tax equals NOK 0.11 per kWh produced. Third, local governments affected by hydropower development are entitled to buy up to 10 percent of the power generated. The yield from this concessionary power is equivalent to the difference between the market price of power and the price for the concession power including the input tax. ${ }^{4}$ In this paper we focus on these revenues as they may be used freely by the local government. Some minor hydropower revenues (concession fees and revenues from reversions) are not included since they are earmarked for business development funds. See Appendix C for a more detailed description of the hydropower revenues.

It is important to take into account that revenue from hydropower is distributed between neighboring local governments affected by the production. The revenue distribution rules are shown in Appendix D. The number of local governments with revenues from hydropower production in our sample varies from year to year, with about 37 percent of the sample size in 2001 to more than 50 percent of the sample in 2007. The hydropower revenue level varies widely between local governments. In 2007 hydropower revenues varied from zero to over NOK 58.500 per capita. Around $50 \%$ of the local governments in our dataset received revenue from hydropower production. Table 1 gives a description of how the hydropower revenues are distributed among all the local governments. It also gives a description of how the different hydropower revenue components are distributed within each total revenue quartile.

\footnotetext{
${ }^{4}$ Input tax: tax claimed when transporting electricity in the power grid.
} 


\section{Data}

The data is collected from various sources; Statistics Norway, The Norwegian Tax Administration, The Norwegian Advisory Commission on Local Government Finance, and The Norwegian Meteorological Institute. A variable description table is given in Appendix C. The table report the specific data source and some descriptive statistics. The dependent variable, local government efficiency of public services, and the reveneue variables are discussed in subsection 3.1. Subsection 3.3 end the data section with a brief discussion of the other included control variables. We refer to subsection 4.1 and Appendix F for a description of the instrument and its components.

\subsection{Efficiency and hydropower revenues}

We use an efficiency measure at local government level, available for the period 20012007, developed by Borge et al. (2008) as dependent variable. This measure is the main indicator of productivity in Norwegian local governments, and has also been used by e.g. Bruns and Himmler (2011) and Revelli and Tovmo (2007), although in different settings than ours. The number of observations vary between 357 and 387 for different years, with a total number of observations equal to 2592 . This covers $86 \%$ of all local governments on average.

Efficiency is measured as the ratio between total output and available resources. The efficiency measure is global in the sense that it relates to overall service provision. The starting point is an output measure based on indicators of production from six main service sectors: care for the elderly, primary and lower secondary education, day-care, welfare benefits, child custody and primary health care. The six sectors account for about $75 \%$ of the local government budgets. In all sectors, service provision is arranged by the local government. All sectors are weighted according to their budget share. The measure relies on a total of 17 indicators of production from the different service sectors. Sector specific indicators are also weighted after budget information, if available. The calculation of the aggregate output measure is as follows:

$$
\text { Output }_{j}=\sum_{s=1}^{S}\left(\alpha_{s}\left(\sum_{i=1}^{I_{s}} \beta_{s i} \frac{x_{s i}^{j}}{\bar{x}_{s i}}\right)\right), \quad \sum_{s=1}^{S} \alpha_{s}=1, \quad \sum_{i=1}^{I_{s}} \beta_{s i}=1,
$$

Here $x_{s i}^{j}$ is indicator $i$ in sector $s$ in local government $j, \bar{x}_{s i}$ is the weighted (by population size) sample mean, and $\alpha$ and $\beta$ are, respectively, sector and indicator weights.

In order to obtain an indicator of efficiency, output must be related to economic resources. Economic resources is measured by per capita revenue (TotalRevenue ${ }_{j t}$ ) within the local government. Efficiency in local public services is then given as:

$$
\text { Efficiency }_{j t}=\frac{\text { Output }_{j t}}{\text { TotalRevenue }_{j t}}
$$

The total revenue variable, TotalRevenue ${ }_{j t}$, equals the sum of general purpose grants, revenue and wealth tax, property tax, natural resource tax and concession power revenue. The revenues are deflated by a local government specific "deflator" capturing spending 
needs variation across local governments and corrected for differences in payroll tax $5^{5}$ Figure 3 plots Output $_{j t}$ and TotalRevenue $j t$ for 2007 in the same graph. It is clear that there is a positive relationship between aggregate output and local government revenue. There is also a substantial variation in aggregate output between local governments with similar levels of revenue. This indicates that some local governments are more efficient that others.

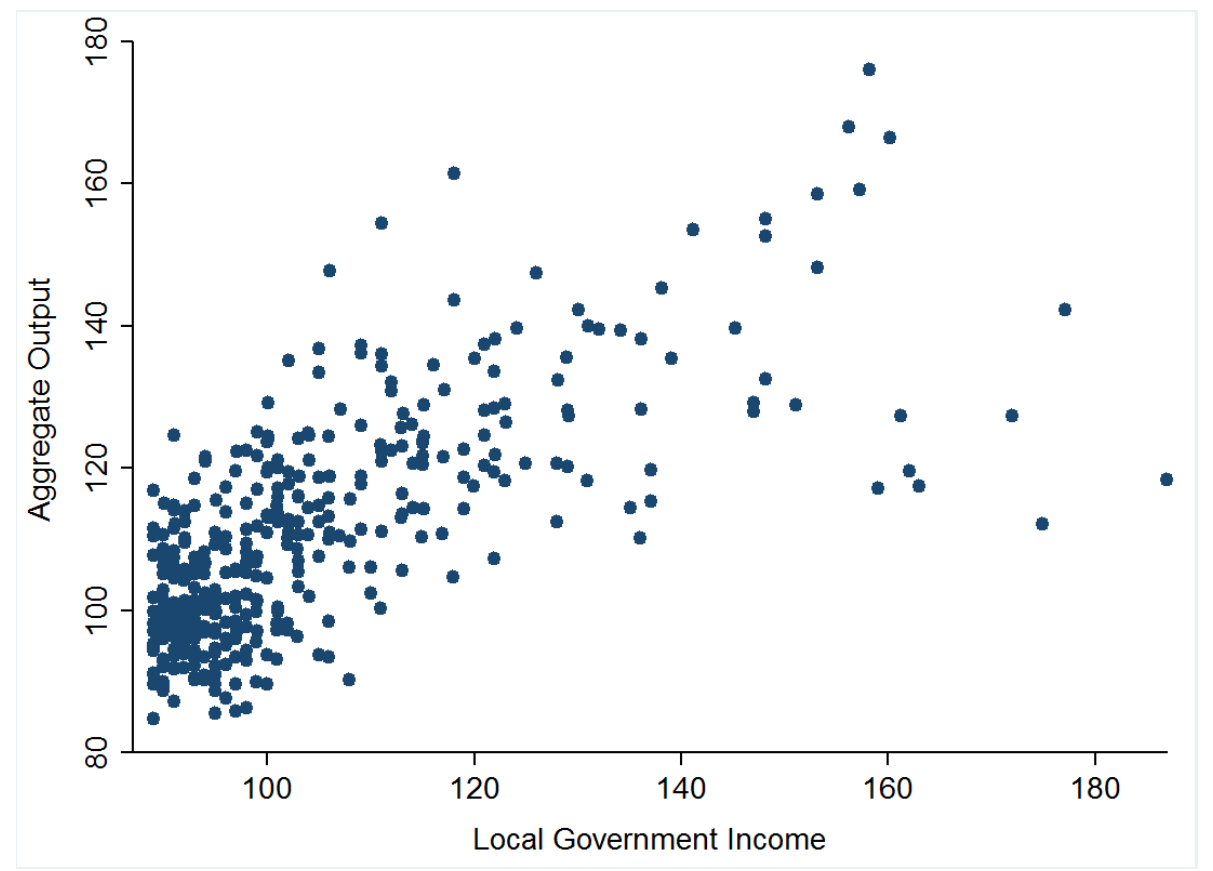

Figure 3: Aggregate output and local government revenue, 2007.

Note: Output and revenue are normalized such that the weighted average equal 100. In order to ease visual interpretation of the plot, three local governments with revenue above 200 are excluded from the figure.

In order to test the rentier state hypothesis, we split the total revenue variable. The revenues collected from the hydropower sector are termed HydroRevenue ${ }_{j t}$, and equals the sum of property tax from hydropower plants, natural resource tax and concession power revenue. All other revenues are contained in the variable OtherRevenue ${ }_{j t}$, and equals the difference between TotalRevenue $e_{j t}$ and HydroRevenue ${ }_{j t}$. Our revenue variables are described in more detail in Appendix C

\subsection{Control variables}

The vector of controls in the empirical specifications capture other factors than revenues that may affect local government efficiency. Factors like democratic participation, political leadership, private revenue, and costs related to topology and climate may all be of importance. First we control for population size to capture eventual economies of scale. Second, we include a variable for sparse population. Settlement patterns may increase

\footnotetext{
${ }^{5}$ Differences in payroll tax are imposed by the central government to stimulate economic activity in rural parts of Norway.
} 
public service costs. Third, as the revenue variable only includes block grants and local taxes, it does not include the effect of revenue from user fees on productivity. It is possible to capture some of this effect by including private gross revenue. High private revenue may carry high user fee revenue. Forth, democratic participation can be measured by voter turnout in local government elections. A high degree of democratic participation may affect inefficiency in public service provision. Fifth, we include a variable termed coalition. This is a dummy variable taking the value one if the mayor is from the leftwing block while the deputy mayor is not, or if the deputy mayor is from the left-wing block while the mayor is not. If the mayor and the deputy mayor are from different blocks this might affect the efficiency of public good production as a result of a more equal balance of power. Finally, topological and climate factors may affect productivity. We include a variable for precipitation deviation from normal values. Years with more precipitation than usual may force higher costs on the local governments. A variable for deviation in temperature from normal values is also included.

\section{Empirical specifications and hypotheses}

We undertake the empirical analysis in two steps. In step 1 we use an instrumental variable approach to investigate if there is an endogeneity problem. We do not find this to be the case. In step 2 we then test what we term "the Paradox of Plenty" hypothesis and "the Rentier State" hypothesis.

\subsection{Step 1: Identification strategy}

Before the identification strategy is discussed further, we define the empirical specification in step 1 as follows:

$$
\text { Efficiency }_{j t}=\alpha+\beta_{1} \text { TotalRevenue }_{j t}+\beta_{3} Z_{j t}+\delta_{t}+\epsilon_{j t}
$$

$Z_{j t}$ is a vector of controls, $\delta_{t}$ is a year-specific constant term, and the $\epsilon_{j t}$ an idiosyncratic error term. The variables included in the $Z_{j t}$ vector are described in Section 3. The empirical specification is first estimated by ordinary least square (OLS) and fixed effect (FE) estimation.

This empirical specification aims to test if high local government revenue reduces the efficiency in production of public goods. OLS and FE estimates cannot necessarily be given a causal interpretation. Revenues might be endogenous and depend on the policies chosen by politicians in response to fiscal needs. It is therefore important to test if there are any endogeneity problems in the revenue variable and its components. This can be done by an instrumental variable approach. As TotalRevenue ${ }_{j t}$ consist of all local revenues, including revenues from the hydropower sector, testing TotalRevenue ${ }_{j t}$ for endogeneity also test the possibility of endogeneity in the resource abundance variable, measured by revenues from hydropower production.

There are two identification problems that may affect our estimations. First, there is a potential for omitted variables. It is likely that revenues are correlated with unobservable 
local government-specific characteristics, as for example political factors and the inhabitants' preferences. Second, the observed total revenue variable may be endogenous. For example, it may be the case that local governments that are less efficient in production of welfare services adjust policy so as to collect higher revenues.

Our identification strategy is to use geographical characteristics and precipitation as instruments. As explained earlier, total revenue variation can in part be explained by difference in hydropower production revenue. We therefore instrument the TotalRevenue ${ }_{j t}$ variable by exogenous variables like precipitation, topology, and meter of rivers in steep terrain, as these characteristics can help us predict the hydropower revenue, and thus capture the variation of revenue among local governments.

The instrument is developed in two stages. First, we provide a general description of the hydropower process to clarify how the production of hydroelectric power is affected by geography and precipitation. We then develop our instrument.

\section{The hydropower process}

Hydro-electrical power production depends on water flow and height of fall given by nature. Norway has been blessed with both of these characteristics through it's climate and topology. There are about 4000 river systems in Norway. These systems comprise rivers and all its tributaries from source to sea, including lakes, snowfields and glaciers. Water inflow depends on the river system and precipitation. The catchment area is the geographical area that collects the precipitation that runs into a river system. Volume and head of water determine the potential energy of a waterfall and therefore the locations of hydropower plants and their potential. ${ }^{6}$

There are two main types of hydropower plants developed in Norway. First, Western Norway, Nordland county and parts of Troms county has relatively steep water systems with steep waterfalls. Here high-head power stations are mainly developed. These plants are constructed to utilize a large head but smaller volume of water. Many of these plants are reservoir power stations, and store water in a reservoir. Water is directed into pressure shafts leading down to the power plant, where it strikes the turbine runner at high pressure. The kinetic energy of the water is transmitted via the propeller shaft to a generator, which converts it into electrical energy (Norwegian Ministry of Petroleum and Energy, 2008). Reservoir power stations allow water to be retained in flood periods and be released in drought periods. See the illustration of a high-head power station in Appendix E. To increase the hydropower production potential, water is transferred from one part of a river system to another, or some places even between neighboring river systems (as shown in the same figure).

Second, and in contrast, Eastern Norway, Trøndelag region and Finnmark county has longer water systems that carry a large water volume but with relatively smaller waterfalls. Then it is often developed low-head power stations, which use large water volume but smaller heads. Most low-head stations are run-of-river power stations. Regulations of the water flow are difficult, so water production varies with the incoming water given by nature. For both high and low-head power stations there are often several stations in the same river system.

\footnotetext{
${ }^{6}$ The head of water is the height difference between reservoir intake and power plant outlet.
} 
The production potential of a hydropower plant, $N(k W)$, is given as

$$
N(k W)=g \cdot \eta \cdot Q\left(m^{3} / s\right) \cdot H(m),
$$

where $g$ equals the acceleration of gravity $\left(9.81 \mathrm{~m} / \mathrm{s}^{2}\right), \eta$ is the total power efficiency of the power plant, $Q$ the maximal usable water flow, and $H$ is the head (the total height of fall).

The price formation for hydropower in Norway is determined by supply and demand in the integrated Nordic power market, but also by the power balance in countries outside this region. Precipitation and inflow to reservoirs are important for potential aggregate production and therefore also for the prices in the Nordic market. In addition temperatures and other weather conditions, inside and outside the Nordic countries, affect the supply and demand of electricity, and will be important for the price formation in the electricity marked.

\section{The instrument}

The instrument utilize the steepness of the river, water volume in the river, volume of precipitation within the nearby catchment area, and price, and equals:

$$
\text { Instrument }_{j t}=\frac{\left[\sum_{w=10}^{w=750}\left(w \cdot \text { River }_{w j}\right)\right] \cdot \text { Precipitation }_{j t} \cdot \text { Price }_{t}}{\text { Population }_{10 j t}}
$$

Here $w$ is water volume classification, River $4_{w j t}$ is meter of river with water volume class $w$ in terrain above 4 degrees in the center local government? Precipitation $_{j t}$ is average precipitation in the center local government and its neighbors, Price $_{t}$ is the real average wholesale price of electricity in Norway, and at last, Population Pojt $_{10}$ is population size lagged 10 years.

The instrument uses different elements from the production process, discussed in section 4.1. to predict if a local government may have hydropower revenue or not. Equation (3) captures the potential for hydropower revenue in the center local government. First, we use water volume data collected from the Norwegian Water Resources and Energy Directorate. They have classified all Norwegian rivers with water volume above $1 \mathrm{~m}^{3} / \mathrm{s}$ into 10 classes. The variable $w$ equals the maximum level in each class 8 . Next, we multiply $w$, with meter of river in terrain above 4 degrees. See Appendix $\mathrm{F}$ for data description and how these variables are calculated. This makes the instrument capture differences in level of hydropower revenue (hydropower production) between the local governments. Next, we multiply this sum by average precipitation $\left(\right.$ Precipitation $_{j t}$ ) and average wholesale price of electricity $\left(\right.$ Price $\left._{t}\right)$. Now the potential for production is multiplied by variables that

\footnotetext{
${ }^{7}$ We follow $\mathrm{NVE}$ and Norconsult (2003) that use 4 degrees as threshold value. We have also tested 12 and 25 degrees, leading to the same results.

We refer to local government $j$ as the center local government. See figure in Appendix F.1 for a graphic illustration.

${ }^{8}$ Classifications $\left(m^{3} / s\right): 1-10,10-50,50-100,100-150,150-200,200-250,250-300,300-400,400-600$, 600-750.
} 
give us some information about time and price variation. Average precipitation gives information about how much precipitation there is within a potential catchment area. The price variable gives information about price fluctuations. Finally, we divide by population size lagged 10 years, to get the instrument in per capita term. We lag the population size to make sure that there is no endogeneity problem between the instrument and the dependent variable. Local governments with no rivers will not gain any hydropower revenue in this instrument.

A valid instrument must satisfy two main criteria. First, the exclusion restriction states that the instrument should only effect the explanatory variable and not the dependent variable. Second, a strong fist-stage relationship is important (Verbeek, 2008). We believe that the exclusion restriction is strongly satisfied in our analysis. Local public productivity should not be correlated with any of our instruments. It may be argued that local governments with heavy snow fall during winter may have some efficiency losses. This is taken into account by applying local government FE in some specifications. To control for precipitation variation over time we include a variable for deviation in precipitation from normal values in each local government. We also include deviation in temperature from normal values.

The second criteria can be assessed by performing a first stage regressions of the form:

$$
\text { TotalRevenue }_{j t}=\sigma+\phi_{1} \text { Instrument }_{j t}+\phi_{2} Z_{j t}+u_{t}+w_{j t}
$$

Here $u_{t}$ is a year-specific constant term that captures any common effects that vary over time, $Z_{j t}$ represent other explanatory variables from the second stage regression, and $w_{j t}$ is the error term. The results document that the instrument is a strong predictor for the total revenue variable. The t-statistics for the instrument in our FE-regression equals 3.22. The corresponding F-value of 10.4 satisfies the rule of thumb for a strong instrument. See Section 5 and Appendix $\mathrm{G}$ for details.

In total, our instrument satisfies the criteria for a good instrumental variable. Nevertheless, all instrument variable estimations must be interpreted with caution. While there is no guarantee that the instruments are valid, by comparing how the estimates changes with these modifications, we obtain some sense of the magnitude and direction of bias in our estimates. An underlying identification assumption in our analysis is that, in absence of hydropower revenue and given all other explanatory variables, productivity outcomes across local governments should not have systematic differences.

\subsection{Step 2: Testing the hypothesis}

In order to test the Rentier State hypothesis, the variable TotalRevenue $j$ is split between hydropower revenue and other revenue. As will be seen by the results in Section 5 , the efficiency retarding effect of public revenues does not seem to be the result of endogeneity problems in our revenue variable. Hence, the main regressions in step 2 will be estimated by OLS and FE, although we also here use our instrument as a robustness check.

The resource curse literature emphasizes that both the size and the composition of revenue may affect productivity. A local government with a high level of revenue may supply a high level of public services even without using the economic resources efficiently. 
A high level of public revenue may, therefore, reduce the incentives for efficient production of public goods. When a local government has high revenues from the natural resource sector, in our case from the hydropower sector, its dependence on raising revenues directly from citizens decrease, possibly making citizens less concerned about how 'their' money is used. In turn, weaker monitoring of politicians may induce inefficiency.

Our econometric specification is as follows:

$$
\begin{aligned}
\text { Efficiency }_{j t}=\alpha & +\beta_{1} \text { HydroRevenue }_{j t}+\beta_{2} \text { OtherRevenue }_{j t} \\
& +\beta_{3} Z_{j t}+\delta_{t}+\epsilon_{j t}
\end{aligned}
$$

All variables are discussed in Section 3. $Z_{j t}$ is a vector of controls, $\delta_{t}$ is a year-specific constant term, and the $\epsilon_{j t}$ an idiosyncratic error term.

We investigate two main hypothesis. The first we refer to as the Paradox of Plenty hypothesis; namely that high revenues in a local government reduces the efficiency in the production of public services, but that it is total revenue and not its composition that matters for efficiency. Thus the Paradox of Plenty hypothesis can be formulated as

$$
\beta_{1}=\beta_{2}<0 .
$$

The other hypothesis we refer to as the Rentier State hypothesis; revenue derived from resource abundance has a more damaging effect on efficiency that revenue derived from other sources. Thus the Rentier State hypothesis can be formulated as

$$
\left|\beta_{1}\right|>\left|\beta_{2}\right|
$$

\section{Empirical Results}

\subsection{Results from step 1}

As explained in the last section we use an instrumental variable approach to rule out endogeneity problems in our regressions. The results are reported in Table 2. As a starting point we report a simple OLS model that only includes year dummies. It appears that the effect is negative and significant. This indicates that higher local government revenue reduces the efficiency in production of public goods. The estimate equals -1.08 , meaning that an increase in total revenue per capita by NOK 1000 will cause a reduction in efficiency equal to 1.08 percentage points on average. Column 2 includes other explanatory variables. The estimated effect of the variable of interest remains almost unchanged. The next column, column 3, report FE regression of the same empirical model. This way we control for all time invariant factors that may vary across local governments. The effect of revenue on efficiency is not changed and it is still highly significant.

If the OLS and FE results suffer from endogeneity, the negative correlation between revenues and productivity cannot be given a causal interpretation. This challenge is addressed by our instrument variable approach. The results are presented in columns 4 and 5. The first stage regression is reported in Appendix $\mathrm{G}$ and shows that the instrument is highly significant in both the IV and the IV/FE regression. We observe that the estimated 
Table 2: Regression results

\begin{tabular}{|c|c|c|c|c|c|}
\hline & $(1)$ & $(2)$ & $(3)$ & $(4)$ & $(5)$ \\
\hline Efficiency & OLS & OLS & $\mathrm{FE}$ & IV & $\mathrm{IV} / \mathrm{FE}^{a}$ \\
\hline Total revenue & $\begin{array}{c}-1.084^{* * *} \\
(0.088)\end{array}$ & $\begin{array}{c}-1.295^{* * *} \\
(0.146)\end{array}$ & $\begin{array}{c}-1.030^{* * *} \\
(0.120)\end{array}$ & $\begin{array}{c}-1.496^{* * *} \\
(0.234)\end{array}$ & $\begin{array}{c}-2.972^{* * *} \\
(1.057)\end{array}$ \\
\hline Population & & $\begin{array}{c}-0.003^{* * *} \\
(0.001)\end{array}$ & $\begin{array}{c}0.001^{* *} \\
(0.001)\end{array}$ & $\begin{array}{c}-0.003^{* * *} \\
(0.001)\end{array}$ & $\begin{array}{c}0.001 \\
(0.001)\end{array}$ \\
\hline Share pop. sparsley & & $\begin{array}{c}8.121^{* * * *} \\
(1.692)\end{array}$ & $\begin{array}{l}-2.325 \\
(6.185)\end{array}$ & $\begin{array}{c}8.459^{* * *} \\
(1.742)\end{array}$ & $\begin{array}{l}-2.448 \\
(6.598)\end{array}$ \\
\hline Priv. gross income & & $\begin{array}{c}0.003^{* * *} \\
(0.001)\end{array}$ & $\begin{array}{c}-0.002^{* *} \\
(0.001)\end{array}$ & $\begin{array}{c}0.003 * * * \\
(0.001)\end{array}$ & $\begin{array}{l}-0.001 \\
(0.001)\end{array}$ \\
\hline Voter turnout & & $\begin{array}{l}-0.119^{*} \\
(0.061)\end{array}$ & $\begin{array}{c}-0.118^{* * * *} \\
(0.044)\end{array}$ & $\begin{array}{l}-0.079 \\
(0.070)\end{array}$ & $\begin{array}{c}-0.098^{*} \\
(0.052)\end{array}$ \\
\hline Coalition & & $\begin{array}{c}0.013 \\
(0.572)\end{array}$ & $\begin{array}{l}1.305^{* *} \\
(0.524)\end{array}$ & $\begin{array}{l}-0.056 \\
(0.566)\end{array}$ & $\begin{array}{c}1.741^{* * *} \\
(0.610)\end{array}$ \\
\hline Temp.dev. & & $\begin{array}{c}-3.271^{* * *} \\
(1.079)\end{array}$ & $\begin{array}{c}-1.814^{* * *} \\
(0.611)\end{array}$ & $\begin{array}{c}-4.599 * * * \\
(1.450)\end{array}$ & $\begin{array}{c}-1.777^{* * * *} \\
(0.651)\end{array}$ \\
\hline Precip.dev. & & $\begin{array}{c}-0.002^{* *} \\
(0.001)\end{array}$ & $\begin{array}{c}-0.003^{* * *} \\
(0.001)\end{array}$ & $\begin{array}{c}-0.003^{* *} \\
(0.001)\end{array}$ & $\begin{array}{c}-0.003^{* * *} \\
(0.001)\end{array}$ \\
\hline Constant & $\begin{array}{c}127.488^{* * *} \\
(1.954)\end{array}$ & $\begin{array}{c}173.002^{* * *} \\
(14.292)\end{array}$ & $\begin{array}{c}155.800^{* * *} \\
(8.496)\end{array}$ & $\begin{array}{c}189.858^{* * *} \\
(19.306)\end{array}$ & \\
\hline R-squared & 0.326 & 0.459 & & 0.450 & \\
\hline $\mathrm{N}$ & 2583 & 2576 & 2576 & 2569 & 2565 \\
\hline Year dummies & YES & YES & YES & YES & YES \\
\hline Estimation period & 2001-2007 & 2001-2007 & 2001-2007 & 2001-2007 & 2001-2007 \\
\hline
\end{tabular}

All t-values are based on standard errors clustered at the local government level.

${ }^{a}$ Results with clustered standard errors are obtained by applying the Stata command xtivreg2, which is an extensions to Stata's official xtivreg. However, this command do not report a constant term.

coefficients become somewhat higher in absolute values in the second stage regressions, thus indicating that, if anything, OLS underestimates the effect of TotalRevenue $e_{j t}$. It does not seem to be the case that the result of higher revenue leading to lower efficiency is due to endogeneity in the revenue variable. In the FE case the estimated coefficient is nearly tripled in absolute value when total revenue is instrumented. However, the confidence intervals of the coefficients in columns 3 and 5 overlap.

Other explanatory variables are also statistically significant. A large population has a negative effect on efficiency in the OLS and FE regressions. For the IV regressions the population coefficient becomes insignificant. This may be a result of limited time variation in the population variable. In contrast, sparsely populated areas has higher efficiency. This effect is, however, insignificant in the FE and IV models. This may also be explained by limited time variation in the variables, which will make the FE estimate inaccurate. The same may also be the case for private gross revenue. It has a positive and strongly significant effect on efficiency in the OLS regression, but also this effect 
becomes insignificant in the FE and IV/FE model. Surprisingly, voter turnout has a negative impact on efficiency, although not strongly significant. The coalition coefficient is positive and highly significant in the FE and IV/FE regressions. This may indicate that balance of power in the local council is important for efficiency. The last two explanatory variables included is deviation in precipitation and temperature from normal values. The coefficients are, as expected, negative. In years with heavy precipitation and/or low temperatures, the efficiency decrease.

\section{$5.2 \quad$ Results from step 2}

As explained in the empirical specification section, the total revenue variable is now split into two components, termed HydroRevenue ${ }_{j t}$ and OtherRevenue ${ }_{j t}$. The estimation results are presented in Table 3. As in step 1 we start out with a simple OLS model that only includes year dummies. It appears that both effects are negative and significant, but there

Table 3: Regression results

\begin{tabular}{|c|c|c|c|}
\hline & (1) & $(2)$ & $(3)$ \\
\hline Efficiency & OLS & OLS & $\mathrm{FE}$ \\
\hline \multirow[t]{2}{*}{ Hydro revenues } & $-1.090^{* * *}$ & $-1.186^{* * *}$ & $-1.009^{* * *}$ \\
\hline & $(0.149)$ & $(0.218)$ & $(0.125)$ \\
\hline \multirow[t]{2}{*}{ Revenues ex. hydro } & $-1.078 * * *$ & $-1.363^{* * *}$ & $-1.067 * * *$ \\
\hline & $(0.127)$ & $(0.146)$ & $(0.139)$ \\
\hline \multirow[t]{2}{*}{ Population } & & $-0.003^{* * *}$ & $0.001^{* *}$ \\
\hline & & $(0.001)$ & $(0.001)$ \\
\hline \multirow[t]{2}{*}{ Share pop. sparsely } & & $8.257^{* * *}$ & -2.524 \\
\hline & & $(1.616)$ & $(6.176)$ \\
\hline \multirow[t]{2}{*}{ Priv. gross income } & & $0.003^{* * *}$ & $-0.002^{* *}$ \\
\hline & & $(0.001)$ & $(0.001)$ \\
\hline \multirow[t]{2}{*}{ Voter turnout } & & $-0.126^{*}$ & $-0.123^{* * *}$ \\
\hline & & $(0.064)$ & $(0.043)$ \\
\hline \multirow[t]{2}{*}{ Coalition } & & -0.003 & $1.316^{* *}$ \\
\hline & & $(0.569)$ & $(0.524)$ \\
\hline \multirow[t]{2}{*}{ Temp.dev. } & & $-3.360^{* * *}$ & $-1.833^{* * *}$ \\
\hline & & $(1.076)$ & $(0.610)$ \\
\hline \multirow[t]{2}{*}{ Precip.dev. } & & $-0.002^{* *}$ & $-0.003^{* * *}$ \\
\hline & & $(0.001)$ & $(0.001)$ \\
\hline \multirow[t]{2}{*}{ Constant } & $127.427^{* * *}$ & $175.684^{* * *}$ & $156.837^{* * *}$ \\
\hline & $(2.678)$ & $(14.635)$ & $(8.472)$ \\
\hline R-squared & 0.326 & 0.459 & \\
\hline $\mathrm{N}$ & 2569 & 2569 & 2569 \\
\hline Year dummies & YES & YES & YES \\
\hline Estimation period & 2001-2007 & $2001-2007$ & $2001-2007$ \\
\hline
\end{tabular}

All t-values are based on standard errors clustered at the local government level. 
is no significant difference between the two. The negative effect of an increase in hydropower revenue is only slightly higher in absolute value compared to the negative effect of an equal increase in other revenue. This result yields support to the Paradox of Plenty hypothesis, while the Rentier State hypothesis is rejected. In column 2, we report an OLS regression that includes all the controls. The estimated effects of the variables of interest remain almost unchanged. Both coefficients are strongly significant and negative, and there is no significant difference between them.

The OLS results may suffer from omitted variable bias. The next step is thus to perform an $\mathrm{FE}$ regression that controls for all time invariant factors that varies across local governments. The FE results are shown in column 3. The coefficient are still remarkably stable and there is no significant difference between the two. Again, as for the OLS results, the FE results yields support to the Paradox of Plenty hypothesis, while the Rentier State hypothesis is rejected. As a robustness check, the same model is estimated with IV and IV/FE using the instrument constructed in section 4.1 on the HydroRevenue j $_{j}$ variable. The results are reported in Appendix $\mathrm{H}$, and support the findings already described.

\section{Robustness}

In this section we provide several robustness checks for our baseline estimates from step 2. Appendix I summarizes the results from the alternative specifications that will be presented below.

First we investigate if our results are sensitive to extreme observations and outliers. The motivation is that there are a few observations with relatively low levels of efficiency. For example, in 2005, the minimum value for the efficiency measure is 45 , but only $1 \%$ of the observations are below 65 . On the other end of the distribution, the maximum value is 135, but only $1 \%$ of the observations is above 125. In columns 1 and 2 in Appendix I we rerun our OLS and FE baseline models excluding observations with efficiency below 80 or above 120. It appears that the results are not driven by outliers with high or low efficiency.

Another concern may be that local governments with high hydropower revenue typically are small and sparsely populated. In our baseline models we control for this by including population size and settlement pattern. To test if this is sufficient, and that there is no other omitted population size variable that affect our estimates, we rerun our baseline regression with an extra dummy variable that equals one if the population size is greater than 10,000. Column 3 and 4 show that the results are robust to this modification.

Our baseline model is static, and it is of interest to investigate if the results carry over to a dynamic specification. In column 5 and 6 we include lagged efficiency as an explanatory variable. Even though the absolute value of our coefficients of interest are reduced in the OLS regression, the effects of hydropower revenues and other revenues are still of similar magnitude.

Finally, it may be argued that the results will be different if we separate between general purpose grants and tax revenues not related to hydropower plants. We test this by doing exactly so; we split other revenue between tax revenues and general purpose grants. The results, shown in column 7 and 8, reveal that the impact of grants and taxes are somewhat different. Still, the hydropower revenue do not seem to harm the efficiency 
of local public good services more than an increase in any of the other revenue variables.

\subsection{Alternative efficiency measure}

In addition we test the results by rerunning the regressions on an alternative efficiency measure, developed by Borge et al. (2008, p. 481 and 492).9 . We term the alternative efficiency measure $\mathrm{E}(\mathrm{A} 2)$. This measure takes into account two weaknesses in the baseline efficiency measure. There will be a tendency to overestimate efficiency in local governments with high user charges, low interest payments and debt service, and large deficits. Left out sector ${ }^{10}$ and imperfect correspondence between revenues and resources devoted to service provision can be accounted for by regressing the baseline efficiency measure on the budget shares for the services that are left out; user charges, interest and debt service, and net operating surplus, separated by year. We then subtract the residuals from the regressions from the baseline efficiency measure to form the alternative efficiency measure. Also this measure is normalized such that the weighted average by population is equal to 100 .

The results is reported in Appendix J]. The estimates of interest are somewhat smaller in absolute value, but our results are still robust. Again, the effects of hydropower revenues and other revenues are of similar magnitude.

\section{Concluding remarks}

We have developed a measure of resource abundance that can be argued to be truly exogenous in the sense that it cannot be affected by endogenous economic decisions. This is used to test the Paradox of Plenty hypothesis and the Rentier State hypothesis. We find support for the Paradox of Plenty hypothesis that higher local government revenue retards efficiency, but no support for the Rentier State hypothesis that resource revenue has more adverse efficiency effects than alternative revenue sources. We hasten to add that this need not imply that rentier state mechanisms are irrelevant in other settings. In particular, one could argue that in weakly institutionalized countries the potential effects hypothesized in the rentier state literature are more likely to manifest themselves, and thus that our rejection of the rentier state hypothesis is conditional on strong institutional quality.

We believe that future research could benefit from using similar measures as ours, or other types of exogenous variation in resource abundance, in settings where institutions are weak. Moreover, it may also be the case that when initial institutions are fragile, they may be further eroded by resource abundance. Our paper has not studied such important questions, as our empirical setting is one with local government variation in resource abundance in a country where initial institutions are robust. Although our study thus cannot be regarded as a general rejection of the Rentier State hypothesis, it does indicate that rentier state mechanisms in not the inevitable outcome of natural resource abundance.

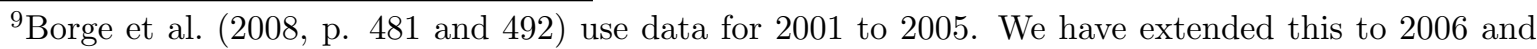
2007 with the same method.

${ }^{10}$ The (minor) service sectors culture, communication, infrastructure, and housing.
} 


\section{References}

Alexeev, M. and Conrad, R. (2009). The elusive curse of oil. Review of Economics and Statistics, 91(3):586-598.

Aslaksen, S. (2010). Corruption and oil: Evidence from panel data. University of Oslo.

Beldring, S., Roald, L. A., and Vokso, A. (2002). Avrenningskart for norge; aarsmiddelverdier for avrenning 1961-1990 [run-of map of norway: Normal values for run-of 1961-1990]. Technical Report 2, Norwegian Water Resources and Energy Directorate. http : //www.nve.no/Global/Publikasjoner/Publikasjoner \%202002/Dokument\%202002/Trykkefil\%202 - 02.pdf.

Borge, L.-E., Falch, T., and Tovmo, P. (2008). Public sector efficiency: the role of political and budgetary institutions, fiscal capacity, and democratic participation. Public Choice, 136:475-495.

Brunnschweiler, C. and Bulte, E. (2008a). Linking natural resources to slow growth and more conflict. Science, 320(5876):616 - 617 .

Brunnschweiler, C. and Bulte, E. (2008b). The resource curse revisited and revised: A tale of paradoxes and red herrings. Journal of Environmental Economics and Management, $55(3): 248-264$.

Bruns, C. and Himmler, O. (2011). Newspaper circulation and local government efficiency. Scandinavian Journal of Economics, 113(2):470-492.

Caselli, F. and Michaels, G. (2011). Do Oil Windfalls Improve Living Standards? Evidence from Brazil. unpublished, LSE.

Collier, P. (2010). The Plundered Planet. Oxford University Press, New York.

Collier, P. and Goderis, B. (2008). Commodity prices, growth and the natural resource curse: Reconciling a conundrum. OxCarre Working Papers, 014.

Dinkelman, T. (August 2010). The effects of rural elecrification on employment: New evidence from south africa. Retrived from http : //www.princeton.edu/rpds/papers/dinkelman lectricity $_{0} 810 . p d f$.

Duflo, E. and Pande, R. (2007). Dams. The Quarterly Journal of Economics, 122(2):601646.

Erlandsen, A. H. (2006). Vannkraftutbygging i Norge (Water power development in Norway). In Kulturminner $i$ norsk kraftproduksjon (Cultural monuments in Norwegian power production), pages 35-70. Norges vassdrags- og energidirektorat (Norwegian Water Resources and Energy Directorate).

Fiva, J. H., Halse, A., and Natvik, G. J. (2012). Local government dataset. Technical report. Availiable at www.jon.fiva.no/data.htm.

Gelb, A. (1988). Oil Windfalls: Blessing or Curse? Oxford University Press, New York. 
Hanssen-Bauer, I., Tveito, O. E., and Szewczyk-Bartnicka, H. (2006). Comparison of grid-based and station-based regional temperature and precipitation series. Technical Report 4, Norwegian Meteorological Institute. http :

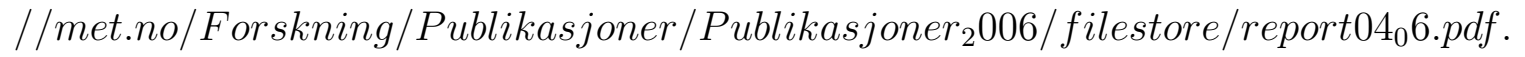

Karl, T. L. (1997). The Paradox of Plenty: Oil Booms and Petro States. Oxford University Press, New York.

Lipscomb, M., Mobarak, A. M., and Barham, T. (2011). Development effects of electrification: Evidence from the geologic placement of hydropower plants in brazil. Retrived from http://econ - www.mit.edu/files/6610.

Mahdavy, H. (1979). M.A. Cook ed., chapter The Patterns and Problems of Economic Development in Rentier States: The Case of Iran. Oxford University Press, London.

Mehlum, H., Moene, K., and Torvik, R. (2006). Institutions and the resource curse. The Economic Journal, 116:1-20.

Monteiro, J. and Ferraz, C. (October 2010). Does oil make leaders unaccountable? working paper, PUC Rio de Janeiro.

Natvik, G. J., Andersen, J. J., and Fiva, J. H. (2011). Voting when the stakes are high. Working Paper 2010/15, Norges Bank.

North, D. and Thomas, R. (1973). The Rise of the Western World: A New Economic History. Cambridge University, New York.

Norwegian Ministry of Petroleum and Energy (2008). Facts 2008. Energy and Water Resources in Norway. Norwegian Ministry of Petroleum and Energy, Oslo.

NVE and Norconsult (2003). Veileder i planlegging, bygging og drift av smaa kraftverk [guide to the proses of plan, build and run a micro hydropower plant]. Technical Report 2, Norwegian Water Resources and Energy Directorate. http : //webby.nve.no/publikasjoner/veileder/2003/veileder $2003_{0} 2$.pdf.

Revelli, F. and Tovmo, P. (2007). Revealed yardstick competition: Local government efficiency patterns in norway. Journal of Urban Economics, 62:121-134.

Sachs, J. and Warner, A. (1995). Natural resource abundance and economic growth. NBER Working Paper, No. 5398.

Tsui, K. K. (2011). More oil, less democracy: Evidence from worldwide crude oil discoveries. The Economic Journal, 121(551):89-115.

Verbeek, M. (2008). A guide to modern econometrics. John Wiley \& Sons, West Sussex. 


\section{A Total revenue linked to hydropower revenue}

Table 4: The 8 richest (per capita) local governments in Norway (2007)

\begin{tabular}{lcccc}
\hline Municipality & $\begin{array}{c}\text { Total } \\
\text { revenue*a }^{* a}\end{array}$ & $\begin{array}{c}\text { Hydro } \\
\text { revenue*b }^{* b}\end{array}$ & $\begin{array}{c}\text { Share } \\
\text { hydro }\end{array}$ & Pop. \\
\hline Bykle & 108,6 & 54,9 & $51 \%$ & 902 \\
Eidfjord & 93,2 & 58,5 & $63 \%$ & 915 \\
Sirdal & 77,0 & 51,6 & $67 \%$ & 1737 \\
Modalen & 75,9 & 42,5 & $56 \%$ & 356 \\
Aurland & 69,1 & 37,0 & $54 \%$ & 1715 \\
Tydal & 58,7 & 31,6 & $54 \%$ & 859 \\
Aseral & 55,9 & 25,2 & $45 \%$ & 893 \\
Suldal & 54,9 & 26,0 & $47 \%$ & 3874 \\
& & & & \\
Mean & & & & \\
All (424) & 30,4 & 2,2 & $5 \%$ & 10830 \\
Hydro $>0$ & 32,6 & 4,3 & $10 \%$ & 9286 \\
Hydro =0 (212) & 28,3 & 0 & - & 12375 \\
& & & & \\
Min (all) & 23,5 & 0 & - & 214 \\
Max (all) & 108,6 & 58,5 & $67 \%$ & 548617 \\
\hline
\end{tabular}

*) 1000 NOK, per capita (1000 NOK = 200 USD). "Deflated" by a cost index, and corrected for differences in payroll taxes.

a) Total revenue $=$ block grants + wealth $\&$ revenue tax + property tax

+ natural resource tax + concession power revenue.

b) Hydro revenue $=$ property tax from hydropower plants + natural resource tax

+ concession power revenue. 


\section{B Developed hydropower plants in Norway}

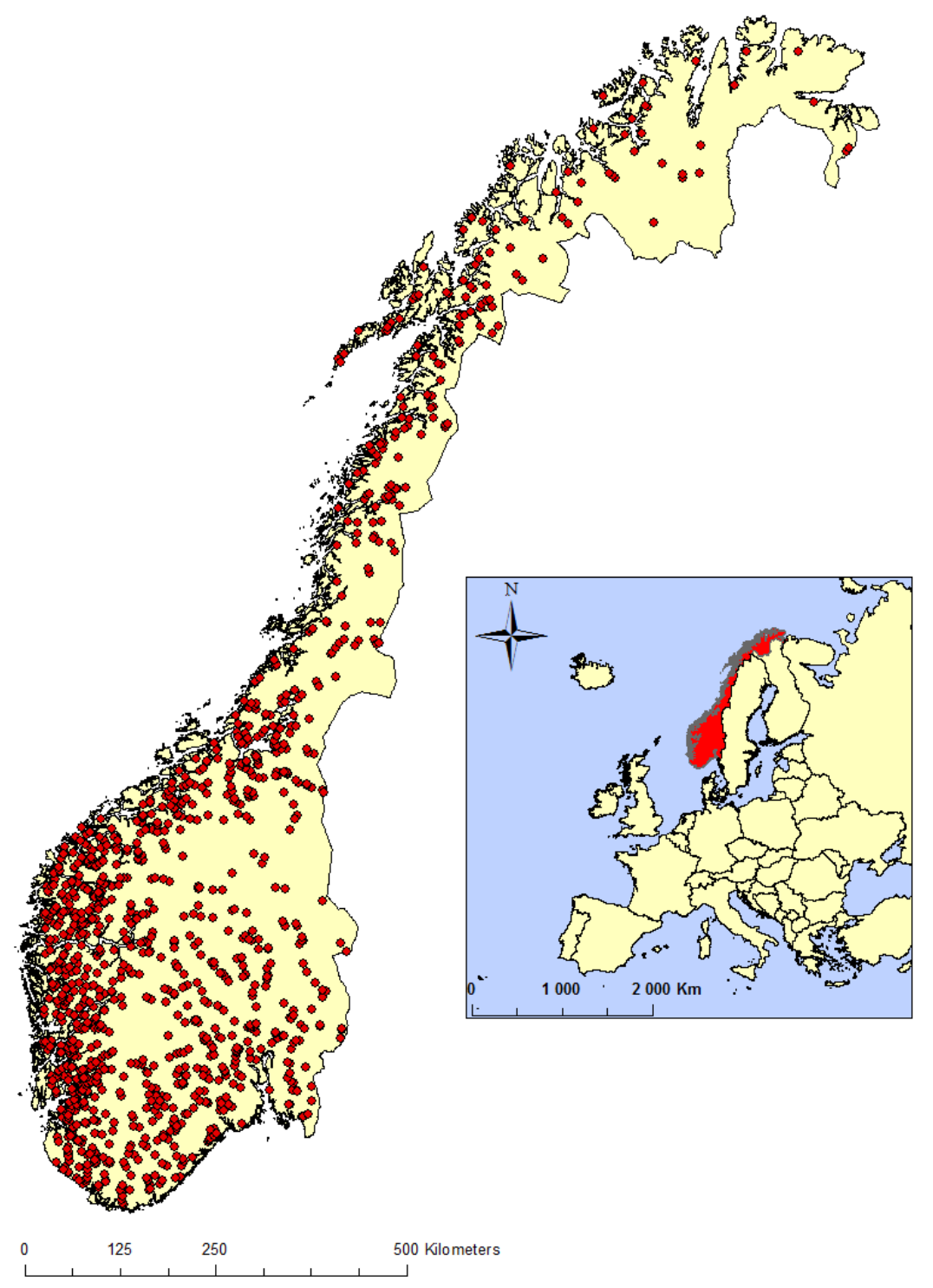

Figure 4: Developed hydropower plants in Norway (2008).

The first hydropower plant in Norway (and Europe) was built as early as in 1885 . In 2010 there where in total 1275 developed hydropower plants, with a total installed capacity equal to $29,636 \mathrm{MW}^{11}$. The same year hydropower energy amounted for over 98 percent of total electricity use in Norway. Most of the production capacity enlargement was done between 1950 and 1990. During the last 25 years there have only been small new installations, owing to the fact that environment and landscape effects have been more important in the concession approval. Yet, the production capacity has increased in

\footnotetext{
${ }^{11}$ See Appendix B for a map of Norwegian hydropower plants. The map illustrates that there are developed hydropower plants in all parts of Norway.
} 
the same period through technological improvements on already established power plants (Erlandsen, 2006).

Local governments are involved in hydropower in two ways. First, many power companies were initially established by larger cities. The purpose was to provide a safe and cheap provision of electricity to their citizens. This role became superfluous after the deregulation of the electricity market in the early 1990s. During the last two decades many power companies are sold and the role of local governments as owners is reduced. Second, the local government where the power plant is located receives taxes and other revenues from the power company. These revenues are considered as compensation for environmental damages, and have been important to generate local support for projects that are profitable for the society at large. This study concentrates on the hydropower revenues received by the local governments affected by hydropower production. Geography is the main factor to decide if a local government is resource abundant or not. This exogenous variation will be used in the empirical identification strategy. 


\section{Variable description and descriptive statistics}

\section{C.1 Dependent variable}

\begin{tabular}{lll}
\hline \hline VARIABLE & VARIABle DesCRIPTION & $\begin{array}{c}\text { MEAN } \\
(\mathrm{ST} . \mathrm{DEV})\end{array}$ \\
\hline \hline Efficiency & Measures the ratio between total output in local public services and available economic resources. See & 104.53 \\
& 3.1 for definition. Source: The Norwegian Advisory Commission on Local Government Finances & $(11.12)$ \\
\hline
\end{tabular}

\section{C.2 Local government revenue}

\begin{tabular}{|c|c|c|}
\hline VARIABLE & $\begin{array}{l}\text { VARIABLE DESCRIPTION } \\
\text { (Variables in } 1000 \mathrm{NOK} \text { ) }\end{array}$ & $\begin{array}{l}\text { MEAN } \\
(\mathrm{ST} . \mathrm{DEV})\end{array}$ \\
\hline $\begin{array}{l}\text { Total } \\
\text { revenue }\end{array}$ & $\begin{array}{l}\text { TotalRevenue }_{j t}=\text { OtherRevenue }_{j t}+\text { HydroRevenue }_{j t} \\
\text { Variables are collected from: Statistics Norway and Norwegian Tax Administration }\end{array}$ & $\begin{array}{l}23.15 \\
(5.72)\end{array}$ \\
\hline $\begin{array}{l}\text { Other } \\
\text { revenue } \\
\text { (ex.hydro) }\end{array}$ & $\begin{array}{l}\text { Local government revenues that are not collected from the hydropower sector. } \\
\text { OtherRevenue }_{j t}=\frac{(\text { block grants }+ \text { revenue andwealthtax }+(\text { prop.tax excl.prop.tax from hydro })) / \text { pop }}{[\text { costindex } /(1+\text { employersfeerate })]} \times(\text { deflator }) \\
\text { Variables are collected from: Statistics Norway }\end{array}$ & $\begin{array}{l}22.7 \\
(4.35)\end{array}$ \\
\hline $\begin{array}{l}\text { Hydro } \\
\text { revenue }\end{array}$ & $\begin{array}{l}\text { Revenues collected from the hydropower sector. } \\
\qquad \text { HydroRevenue }_{j t}=\frac{(\text { prop.tax from hydro }+ \text { natural resourcetax }+ \text { concession power }) / \text { pop }}{[\text { costindex } /(1+\text { employersfeerate })]} \times(\text { deflator }) \\
\text { Variables are collected from: Statistics Norway and Norwegian Tax Administration }\end{array}$ & $\begin{array}{l}0.805 \\
(2.80)\end{array}$ \\
\hline
\end{tabular}




\section{C.2 Local government revenue (continued)}

\begin{tabular}{lll}
\hline \hline VARIABLE & $\begin{array}{l}\text { VARIABLE DESCRIPTION } \\
\text { (Variables in 1000 NOK) }\end{array}$ & $\begin{array}{l}\text { MEAN } \\
\text { (ST.DEV) }\end{array}$ \\
\hline $\begin{array}{l}\text { Local } \\
\text { government } \\
\text { specific } \\
\text { deflator }\end{array}$ & $\begin{array}{l}\text { The local government specific deflator is a weighted average of wage growth and price growth in the } \\
\text { goods and service sector used by local governments. Base year = 2001. Collected from: Ministry of Labor } \\
\text { (Rapporter fra TBU) }\end{array}$ \\
\hline $\begin{array}{l}\text { Employer's } \\
\text { National }\end{array}$ & $\begin{array}{l}\text { Most local governments must pay the Employer's National Insurance fee for its employees to the state, } \\
\text { as part of the finance program of the National Insurance Scheme. The fee is a percentage of the wage. }\end{array}$ \\
$\begin{array}{l}\text { Fee } \\
\text { Focal }\end{array}$ & $\begin{array}{l}\text { Some local governments do not have to pay the fee, and the percentage varies from 0 to 14.1. Collected } \\
\text { government }\end{array}$ \\
$\begin{array}{l}\text { frome The Norwegian Tax Administration } \\
\text { index }\end{array}$ & $\begin{array}{l}\text { Each year, the local governments are given a cost index from spending needs equalization system. } \\
\text { Thervices. Local governments with less costs than the national average cost level will redistribute some } \\
\text { of their revenue to local governments with relatively high costs given average costs. The cost level } \\
\text { of local public services is calculated individually for all local governments given expenditure weights } \\
\text { and certain criteria. These includes unfavorable cost conditions related to population size, settlement } \\
\text { pattern, the age composition of the population, and social factors. The overall average value each year } \\
\text { is equal to 1. Collected from: Ministry of Local Government and Regional Development (Grønt hefte) }\end{array}$ \\
\hline
\end{tabular}




\section{C.3 Hydropower revenue at local government level}

\begin{tabular}{|c|c|c|}
\hline VARIABLE & $\begin{array}{l}\text { VARIABLE DESCRIPTION } \\
\text { (Variables in } 1000 \text { NOK) }\end{array}$ & $\begin{array}{l}\text { MEAN } \\
\text { (ST.DEV) }\end{array}$ \\
\hline $\begin{array}{l}\text { Property } \\
\text { tax from } \\
\text { hydropower } \\
\text { plants }\end{array}$ & $\begin{array}{l}\text { The Norwegian municipalities are free to impose a property tax on the production plants. The tax basis is } \\
\text { calculated on the market value of the property. Because the market value of the property among other factors } \\
\text { depends on the market price of hydropower over the last } 5 \text { years, so will the property tax. By law the minimum } \\
\text { basis of the property tax is NOK } 0.95 \mathrm{kWh} \text {, and the maximum is NOK } 2.35 \mathrm{kWh} \text {. The tax rate is set between } 0.2 \\
\text { and } 0.7 \text { percent. The property tax applies to plants larger than } 10.000 \text { Kilo Volt Amperes (kVA). The property } \\
\text { tax is a pure municipality tax, and can be used as free assets. Yet, the county authority will take property tax } \\
\text { revenue level into consideration when distributing other transfers. Source: Property tax basis is collected from } \\
\text { Norwegian Tax Administration. Tax rate data is only available for year } 2003,2005 \text { and } 2007 \text {. Data for } 2007 \text { is } \\
\text { collected from Statistics Norway for } 2007 \text {, data from } 2003 \text { and } 2005 \text { is collected from The National Federation of } \\
\text { House Owners in Norway. We set the tax rate in } 2001,2002 \text { and } 2004 \text { equal to the tax rate in } 2003 \text {. The tax rate } \\
\text { in } 2006 \text { is set equal to the tax rate in 2005. Source: Norwegian Tax Administration }\end{array}$ & $\begin{array}{l}2210 \\
(7721)\end{array}$ \\
\hline $\begin{array}{l}\text { Natural } \\
\text { resource tax }\end{array}$ & $\begin{array}{l}\text { Applies to power stations. NOK } 0.011 / \mathrm{kWh} \text { is allocated to the municipality authority. The tax ensures that } \\
\text { the local governments have a minimum tax revenue level. The tax base for this tax is calculated for each power } \\
\text { plant, and is the average of the plant's total output of electricity in the revenue year and the six preceding years. } \\
\text { As from } 2004 \text {, the tax base includes only generators with a minimum output of } 5500 \mathrm{kwh} \text {. The natural resource } \\
\text { tax enters into the revenue equalization program, and parts of the tax will be redistributed through lower state } \\
\text { transfers. Source: Statistics Norway }\end{array}$ & $\begin{array}{l}1433 \\
(5438)\end{array}$ \\
\hline
\end{tabular}




\section{C.3 Hydropower revenue at local government level (continued)}

\begin{tabular}{|c|c|c|}
\hline VARIABLE & $\begin{array}{l}\text { VARIABLE DESCRIPTION } \\
\text { (Variables in } 1000 \text { NOK) }\end{array}$ & $\begin{array}{l}\text { MEAN } \\
\text { (ST.DEV) }\end{array}$ \\
\hline $\begin{array}{l}\text { Concessionar? } \\
\text { power }\end{array}$ & $\begin{array}{l}\text { Concessionary power is the yield of power due to concession conditions. Municipal authorities affected by hy- } \\
\text { dropower development are entitled to buy up to } 10 \text { per cent of the power generated. The power bought must not } \\
\text { exceed general power consumption within the municipality. The yield from this concessionary power is equivalent } \\
\text { to the difference between the price for power in the market and the price for the concession power including the } \\
\text { input tax. Some municipalities may choose to sell concession power as full cost to the inhabitants; this gives zero } \\
\text { in profits. The concession power price corresponds to generating costs. There are currently two price setting reg- } \\
\text { ulations. For licenses issued before 1959, the price is negotiated between the licensee and the municipal authority, } \\
\text { limited to a maximum price. For licenses issued after 1959, the price is set by the Ministry of Petroleum and } \\
\text { Energy in accordance full costs for a representative selection of power stations. Source: Statistics Norway }\end{array}$ & $\begin{array}{l}1054 \\
(3126)\end{array}$ \\
\hline $\begin{array}{l}\text { Other minor } \\
\text { revenues } \\
\text { (not in datase }\end{array}$ & $\begin{array}{l}\text { The concessions fees are formal compensation for damage caused to districts in which water resources are exploited. } \\
\text { The fee enters into a distinct fund that is used to improve the industry and commerce within the local community. } \\
\text { tThe revenue from reversions enters when the Norwegian state use its right of reversion of a power plant when a } \\
\text { license expires, usually after } 60 \text { years. The local government(s) affected by this reversion can claim up to } \frac{1}{3} \text { of the } \\
\text { ownership or the dividend. These transfers are often earmarked and locked up in a fund. A business development } \\
\text { fund may be imposed on the licensee. The purpose of this fund is to strengthen affected local industrial and } \\
\text { commercial development. }\end{array}$ & \\
\hline
\end{tabular}




\section{C.4 Other explanatory variables}

\begin{tabular}{|c|c|c|}
\hline VARIABLE & VARIABLE DESCRIPTION & $\begin{array}{l}\text { MEAN } \\
(\text { ST.DEV) }\end{array}$ \\
\hline Population & Total population size in the beginning for the year. Source: Statistics Norway & $\begin{array}{l}11281 \\
(31220)\end{array}$ \\
\hline $\begin{array}{l}\text { Sparsely } \\
\text { populated }\end{array}$ & Share of population that lives in sparsely populated areas. Source: Statistics Norway & $\begin{array}{l}0.48 \\
(0.26)\end{array}$ \\
\hline $\begin{array}{l}\text { Voter } \\
\text { turnout }\end{array}$ & $\begin{array}{l}\text { Voter turnout in the local government election, i.e. the number of votes as a percentage of the number } \\
\text { of eligible voters. Source: Statistics Norway }\end{array}$ & $\begin{array}{l}58.76 \\
(3.70)\end{array}$ \\
\hline $\begin{array}{l}\text { Private } \\
\text { gross } \\
\text { revenue }\end{array}$ & Aggregated private gross revenue after tax (1000 NOK). Source: Statistics Norway & $\begin{array}{l}8826 \\
(25158)\end{array}$ \\
\hline Coalition & $\begin{array}{l}\text { A dummy variable taking the value one if the mayor is from the left-wing block while the deputy } \\
\text { mayor is not, or if the deputy mayor is from the left-wing block while the mayor is not. Source: Fiva } \\
\text { et al. (2012) }\end{array}$ & $\begin{array}{l}0.36 \\
(0.48)\end{array}$ \\
\hline $\begin{array}{l}\text { Deviation } \\
\text { precipitation }\end{array}$ & $\begin{array}{l}\text { Deviation in precipitation from normal values within a municipality ( } \mathrm{mm}) . \text { Source: The Norwegian } \\
\text { Meteorological Institute, calculated in ArcGIS }\end{array}$ & $\begin{array}{l}1166 \\
(256)\end{array}$ \\
\hline $\begin{array}{l}\text { Deviation } \\
\text { temperature }\end{array}$ & $\begin{array}{l}\text { Deviation in temperature from normal values within a municipality }\left({ }^{\circ} \mathrm{C}\right) . \quad \text { Source: The Norwegian } \\
\text { Meteorological Institute, calculated in ArcGIS }\end{array}$ & $\begin{array}{l}11.4 \\
(0.58)\end{array}$ \\
\hline
\end{tabular}

\section{C.5 Variables in instrument}

\begin{tabular}{|c|c|c|}
\hline VARIABLE & "VARIABLE DESCRIPTION & $\begin{array}{l}\text { MEAN } \\
(\text { ST.DEV) }\end{array}$ \\
\hline $\begin{array}{l}\text { Hydro } \\
\text { Potential }\end{array}$ & See section 4.1 and Appendix $\mathrm{F}$ & $\begin{array}{l}2.43 \cdot 10^{7} \\
\left(6.14 \cdot 10^{7}\right.\end{array}$ \\
\hline
\end{tabular}




\section{Hydropower revenue distribution rules between local governments}

Table 5: revenue distribution between municipalities

\begin{tabular}{|c|c|c|c|}
\hline Variable & License & Municipality & Distribution \\
\hline \multirow{5}{*}{$\begin{array}{l}\text { Concession } \\
\text { power }\end{array}$} & \multirow{2}{*}{$\begin{array}{l}\text { Acquire } \\
\text { license }\end{array}$} & Waterfall & $97 \%$ \\
\hline & & Power plant & $3 \%$ \\
\hline & \multirow{3}{*}{$\begin{array}{l}\text { Regulatory } \\
\text { license }\end{array}$} & Reservoir & $48.5 \%$ \\
\hline & & Waterfall and Transfer & $48.5 \%$ \\
\hline & & Power plant & \\
\hline $\begin{array}{l}\text { Natural } \\
\text { resource } \\
\text { tax }\end{array}$ & \multicolumn{3}{|c|}{$\begin{array}{l}\text { Redistributed to the municipalities that are affected by the water } \\
\text { power development and regulation. The more affected the local gov- } \\
\text { ernment is the greater share of the tax they receive. The rules for this } \\
\text { distribution is given in The Taxation Act } \S 18-7 \text {. }\end{array}$} \\
\hline $\begin{array}{l}\text { Property } \\
\text { tax }\end{array}$ & \multicolumn{3}{|c|}{$\begin{array}{l}\text { Similar to the natural resource tax redistribution. Rules are given in } \\
\text { The Act on Property Tax to the Municipalities } \S 8 \mathrm{~A} \text {. }\end{array}$} \\
\hline
\end{tabular}

\section{E Hydopower production}

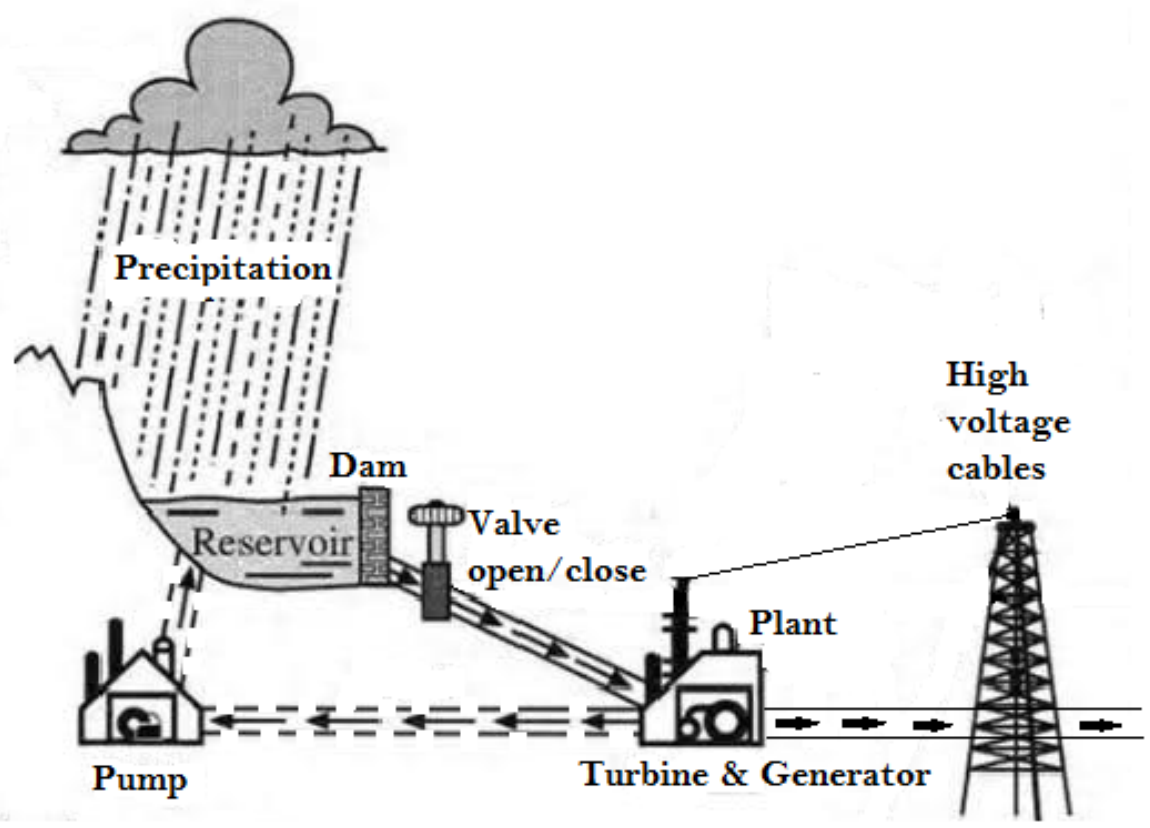

Figure 5: Generation of hydro-electricity by a high-head power plant 


\section{F Variables in instrument}

\section{F.1 Precipitation}

Precipitation data is collected from Norwegian Meteorological Institute. The data consists of $1 \times 1 \mathrm{~km}$. gridded monthly and annual precipitations values. We also have a $1 \times 1 \mathrm{~km}$. gridded dataset of normal (average) precipitation over the period 1961-1990. The gridded datasets are established by a spatial interpolation method. The methodology is reported in Hanssen-Bauer et al. (2006).

Using ArcGIS $10^{12}$ we calculate the average precipitation values within each local government and its neighboring local governments for each year. A visual map is shown in Figure 6. The highlighted area show Vinje local government (the center local government in this example) and its neighbors.

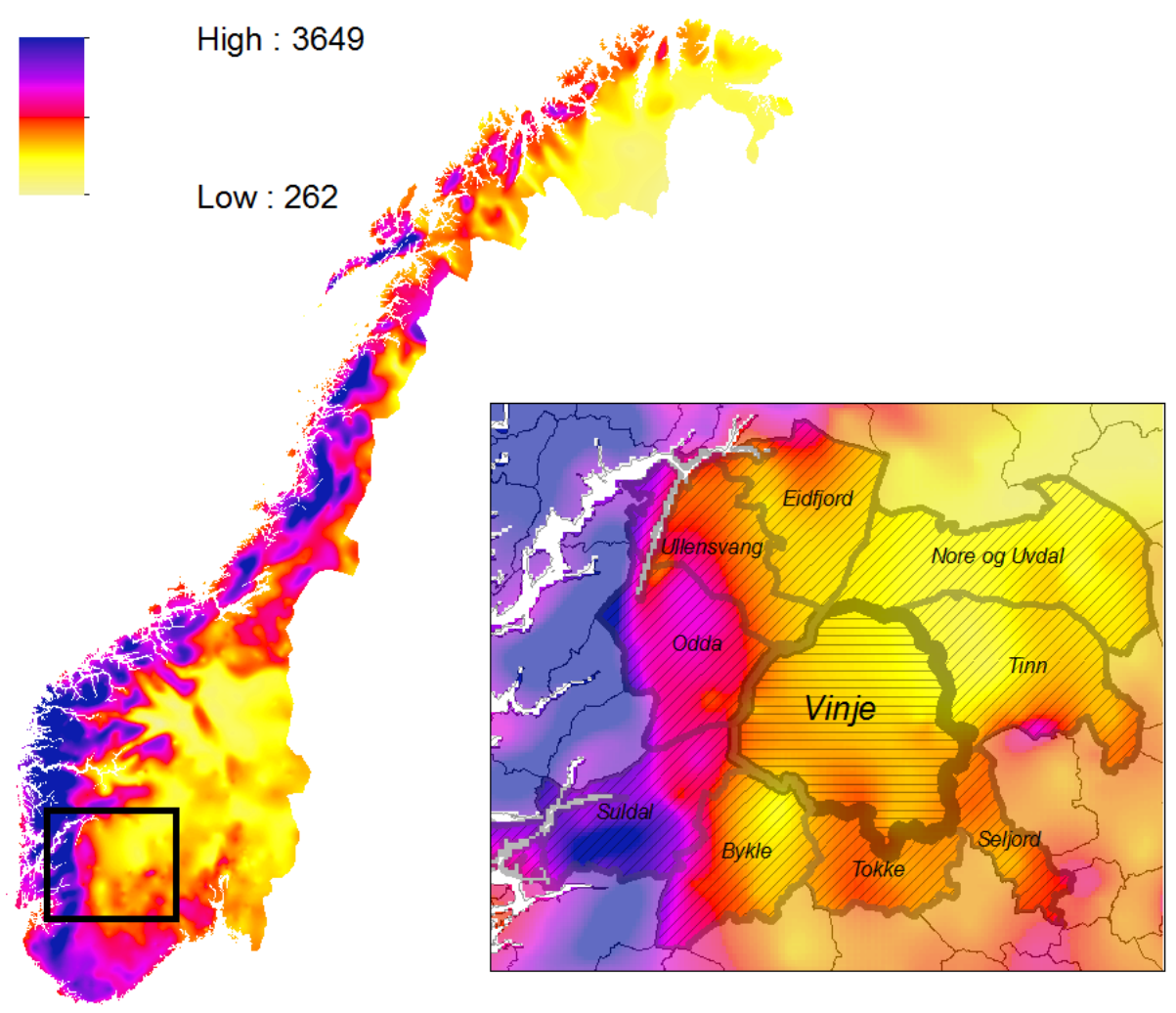

Figure 6: Average precipitation (mm.) in Norway, year 2001

\footnotetext{
${ }^{12}$ ArcGIS consists of a group of geographic information system (GIS) software products produced by Esri.
} 


\section{F.2 Gradient data}

The gradient data is calculated in ArcGIS using a terrain model collected from Norway Digital ${ }^{13}$. The terrain model consists of 50x50 meter grids and has a standard deviation equal to \pm 4 to 6 meter for its heights values 14 . Once one has a good terrain model it is easy to calculate the average gradient within each local government. Figure 7 shows the terrain model of Norway, and the corresponding slope map. Both maps consist of 50x50 meter grids.

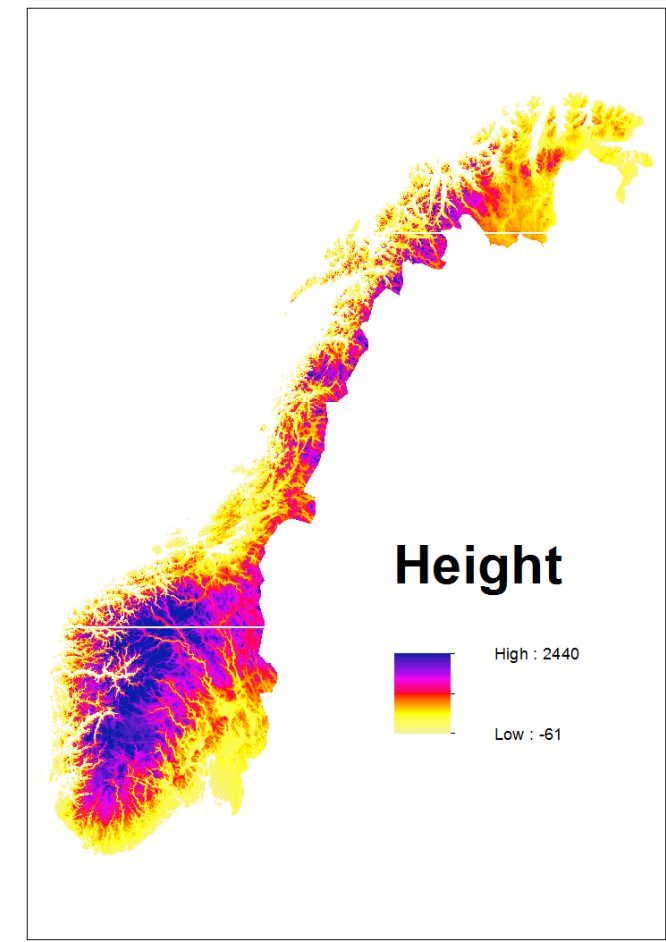

(a) Terrain model

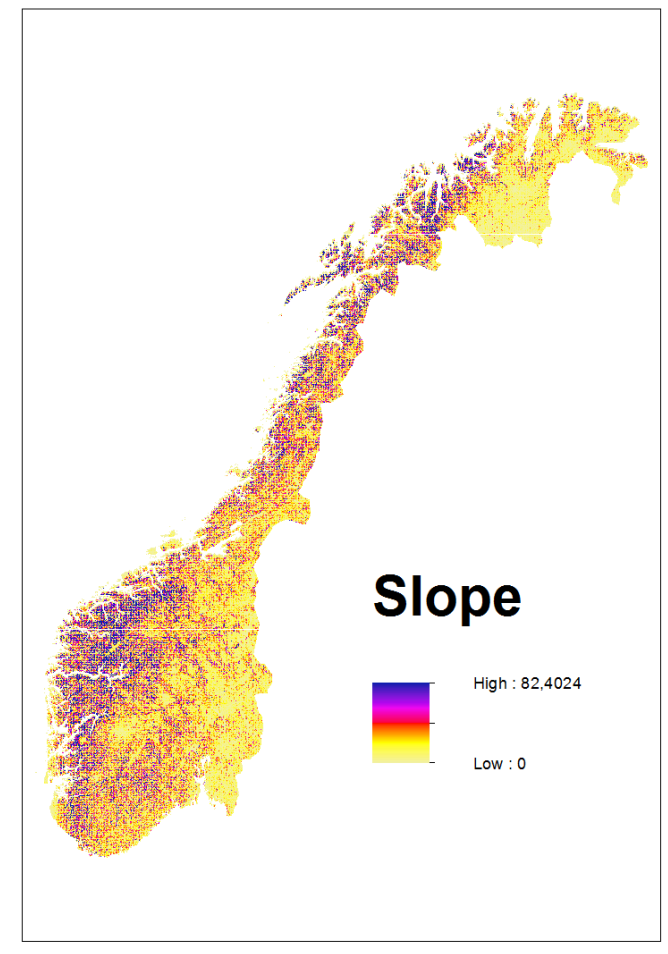

(b) Slope

Figure 7: Terrain and slope map of Norway

\footnotetext{
${ }^{13}$ Norway Digital - the national geographical infrastructure. See: http : //www.statkart.no/Norge digitalt/Engelsk/About $_{N}$ orway $_{D}$ igital/.

${ }^{14}$ Information about the terrain model is given by the Norwegian Mapping Authorities, see: http ://www.statkart.no/statkart.ny.no/nor/Land/Kart g $_{p}$ rodukter/Terrengmodell/ $50_{m}$ eters s $_{\text {rid }}$ Terrengmodell + med $+50+$ meters + grid.d25 - SwtLY27.ips.
} 


\section{F.3 River data}

River data is collected from the Norwegian Water Resources and Energy Directorate (NVE). The data reports all rivers (with water run-of above $1 \mathrm{~m}^{3} / \mathrm{s}$ ) in Norway naturally generated from lakes and rivers. NVE has coupled this data with water run-of variation and in turn classified the water run-of for all the rivers 15 . The rivers are classified into 10 groups given their run-off volume, as shown in figure 8 . We have calculated how many meters of river each local government have. This is also been done separately for all river classifications.

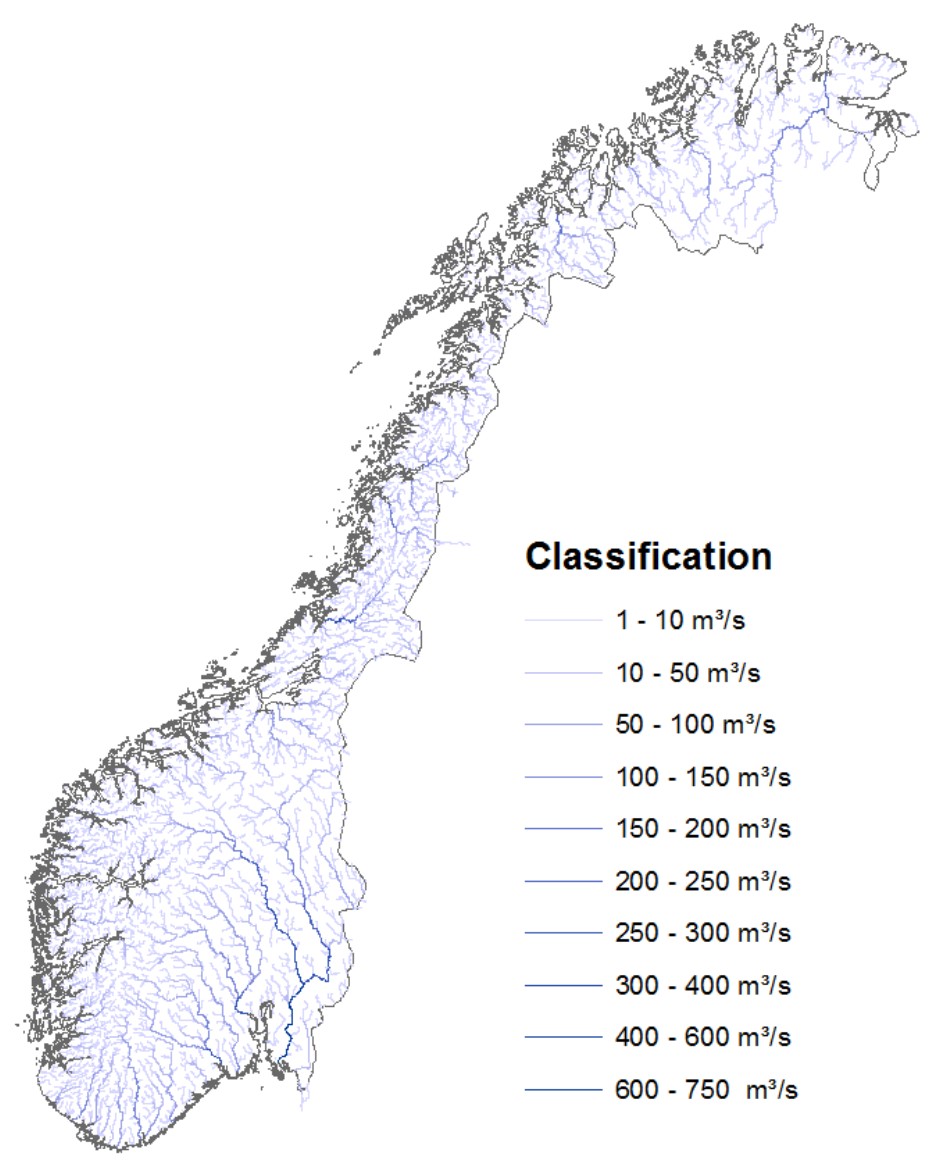

Figure 8: River network classification. Run-off in $\mathrm{m}^{3} / \mathrm{s}$ in the period 1960-1991

\footnotetext{
${ }^{15}$ Their water run-of calculations is reported in Beldring et al. (2002). Unfortunately, this report is available only in Norwegian
} 


\section{Meters of river at locations with a slope above 4 degrees}

As a final calculation in ArcGIS we calculated how many meter of river each local government has in areas with a slope above 4 degrees ${ }^{16}$. This is done by coupling the gradient data with river data. Figure 9 shows an example with Bykle local government, the local government with most hydro power revenue per capita. Bykle has $267.5 \mathrm{~km}$. of river, in witch $84 \mathrm{~km}$. are in areas with slope above 4 degrees.
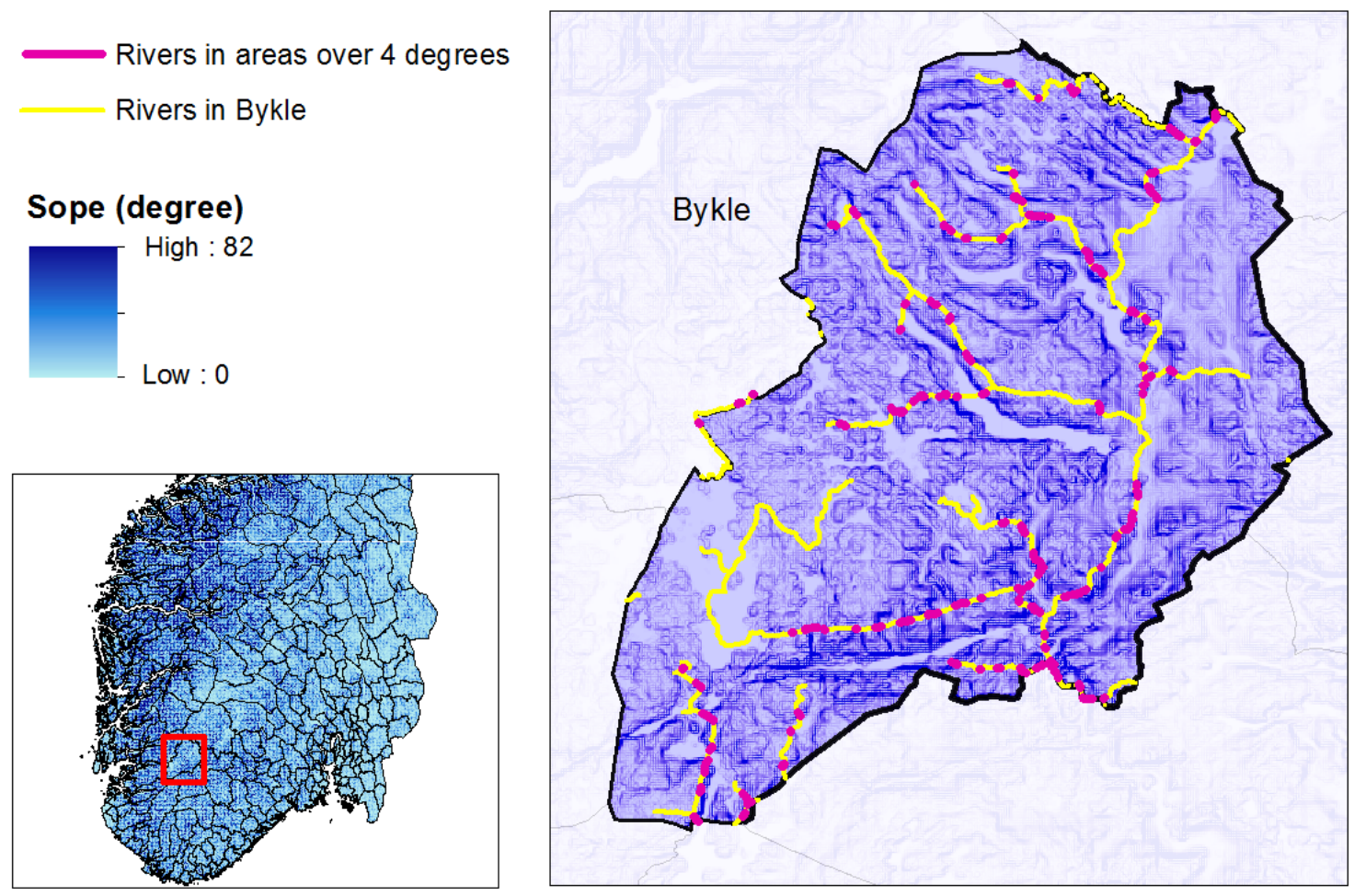

Figure 9: Rivers in Bykle local government: Rivers (above $1 \mathrm{~m}^{3} / \mathrm{s}$ ) in areas with slope above 4 degrees.

\footnotetext{
${ }^{16}$ We follow NVE and Norconsult (2003) that use 4 degrees as threshold value. We have also tested 12 and 25 degrees, leading to the same results.
} 


\section{G First stage regression}

Table 6: First Stage

\begin{tabular}{lcc}
\hline \hline & $(1)$ & $(2)$ \\
TotalRevenue & $\mathrm{IV}$ & $\mathrm{IV} / \mathrm{FE}$ \\
\hline Instrument & $1.65 \cdot 10^{-7 * * *}$ & $5.66 \cdot 10^{-8 * * *}$ \\
& $\left(5.54 \cdot 10^{-8}\right)$ & $\left(1.76 \cdot 10^{-8}\right)$ \\
Population & -0.000 & $-0.000^{* *}$ \\
& $(0.000)$ & $(0.000)$ \\
Share pop. sparsely & 0.290 & -0.546 \\
& $(1.352)$ & $(1.812)$ \\
Priv. gross income & 0.000 & $0.000^{* * *}$ \\
& $(0.000)$ & $(0.000)$ \\
Voter turnout & $0.108^{* *}$ & 0.008 \\
& $(0.050)$ & $(0.012)$ \\
Coalition & -0.003 & 0.206 \\
Temp.dev. & $(0.297)$ & $(0.184)$ \\
& $-5.179^{* * *}$ & -0.016 \\
Precip.dev. & $(0.730)$ & $(0.150)$ \\
& $-0.005^{* * *}$ & -0.000 \\
Constant & $(0.001)$ & $(0.000)$ \\
& $74.011^{* * *}$ & $22.593^{* * *}$ \\
\hline R-squared & $(8.112)$ & $(2.250)$ \\
N & 0.363 & \\
Year dummies & 2569 & 2569 \\
Clustered st.errors & YES & YES \\
Estimation period & $2001-2007$ & $2001-2007$ \\
\hline \hline$*$ * $p$ 0.10, ${ }^{* *} p<0.05, * * *<0.01$ & \\
& &
\end{tabular}




\section{H Instrumenting hydropower revenue}

Table 7: Instrumenting hydropower revenue

\begin{tabular}{|c|c|c|c|c|}
\hline & (1) & $(2)$ & $(3)$ & (4) \\
\hline Efficiency & OLS & FE & IV(hydro) & IV /FE(hydro) \\
\hline Hydro revenues & $\begin{array}{c}-1.186^{* * *} \\
(0.218)\end{array}$ & $\begin{array}{c}-1.009^{* * *} \\
(0.125)\end{array}$ & $\begin{array}{c}-1.731^{* * *} \\
(0.457)\end{array}$ & $\begin{array}{c}-2.754^{* * *} \\
(0.866)\end{array}$ \\
\hline Revenues ex. hydro & $\begin{array}{c}-1.363^{* * *} \\
(0.146)\end{array}$ & $\begin{array}{c}-1.067^{* * *} \\
(0.139)\end{array}$ & $\begin{array}{c}-1.240^{* * *} \\
(0.217)\end{array}$ & $\begin{array}{c}-2.063^{* * *} \\
(0.450)\end{array}$ \\
\hline Population & $\begin{array}{c}-0.003^{* * *} \\
(0.001)\end{array}$ & $\begin{array}{l}0.001 * * \\
(0.001)\end{array}$ & $\begin{array}{c}-0.003^{* * *} \\
(0.001)\end{array}$ & $\begin{array}{l}0.001^{* *} \\
(0.001)\end{array}$ \\
\hline Share pop. sparsley & $\begin{array}{c}8.257^{* * * *} \\
(1.616)\end{array}$ & $\begin{array}{l}-2.524 \\
(6.176)\end{array}$ & $\begin{array}{c}7.938^{* * *} \\
(1.711)\end{array}$ & $\begin{array}{l}-1.693 \\
(6.259)\end{array}$ \\
\hline Priv. gross income & $\begin{array}{c}0.003^{* * *} \\
(0.001)\end{array}$ & $\begin{array}{c}-0.002^{* *} \\
(0.001)\end{array}$ & $\begin{array}{c}0.003^{* * *} \\
(0.001)\end{array}$ & $\begin{array}{c}-0.001^{* *} \\
(0.001)\end{array}$ \\
\hline Voter turnout & $\begin{array}{c}-0.126^{*} \\
(0.064)\end{array}$ & $\begin{array}{c}-0.123^{* * *} \\
(0.043)\end{array}$ & $\begin{array}{l}-0.070 \\
(0.075)\end{array}$ & $\begin{array}{l}-0.054 \\
(0.056)\end{array}$ \\
\hline Coalition & $\begin{array}{l}-0.003 \\
(0.569)\end{array}$ & $\begin{array}{l}1.316^{* *} \\
(0.524)\end{array}$ & $\begin{array}{c}0.017 \\
(0.576)\end{array}$ & $\begin{array}{c}1.648^{* * *} \\
(0.616)\end{array}$ \\
\hline Temp.dev. & $\begin{array}{c}-3.360^{* * *} \\
(1.076)\end{array}$ & $\begin{array}{c}-1.833^{* * *} \\
(0.610)\end{array}$ & $\begin{array}{c}-3.961^{* * *} \\
(1.163)\end{array}$ & $\begin{array}{c}-1.541^{* *} \\
(0.633)\end{array}$ \\
\hline Precip.dev. & $\begin{array}{c}-0.002^{* *} \\
(0.001)\end{array}$ & $\begin{array}{c}-0.003^{* * *} \\
(0.001)\end{array}$ & $\begin{array}{c}-0.003^{* *} \\
(0.001)\end{array}$ & $\begin{array}{c}-0.002^{* * *} \\
(0.001)\end{array}$ \\
\hline Constant & $\begin{array}{c}175.684^{* * *} \\
(14.635)\end{array}$ & $\begin{array}{c}156.837^{* * * *} \\
(8.472)\end{array}$ & $\begin{array}{c}177.089^{* * *} \\
(15.828)\end{array}$ & \\
\hline R-squared & 0.459 & & 0.444 & \\
\hline $\mathrm{N}$ & 2569 & 2569 & 2569 & 2565 \\
\hline Year dummies & YES & YES & YES & YES \\
\hline Estimation period & 2001-2007 & 2001-2007 & 2001-2007 & 2001-2007 \\
\hline \multicolumn{5}{|l|}{ First stage } \\
\hline Hydro revenue & & & $(3)$ & (4) \\
\hline Instrument & & & $\begin{array}{c}7.50 \cdot 10^{-8 * * *} \\
\left(2.54 \cdot 10^{-8}\right)\end{array}$ & $\begin{array}{c}6.45 \cdot 10^{-8 * * *} \\
\left(1.88 \cdot 10^{-8}\right)\end{array}$ \\
\hline Control variables & & & YES & YES \\
\hline Year dummies & & & YES & YES \\
\hline R-squared & & & 0.311 & \\
\hline
\end{tabular}

All t-values are based on standard errors clustered at the local government level. 


\section{Robustness}

Table 8: Robustness regressions

\begin{tabular}{|c|c|c|c|c|c|c|c|c|}
\hline \multirow[b]{3}{*}{ Efficiency } & \multicolumn{2}{|c|}{$80 \leq E f f . \leq 100$} & \multicolumn{2}{|c|}{$\overline{\text { Dummy:Pop }>10,000}$} & \multicolumn{2}{|c|}{ Incl. Eff._-1 } & \multicolumn{2}{|c|}{ Separate income } \\
\hline & (1) & (2) & (3) & (4) & $(5)$ & (6) & (7) & (8) \\
\hline & OLS & FE & OLS & $\mathrm{FE}$ & OLS & $\mathrm{FE}$ & OLS & $\mathrm{FE}$ \\
\hline Hydro revenues & $\begin{array}{c}-1.297^{* * *} \\
(0.156)\end{array}$ & $\begin{array}{c}-1.120^{* * *} \\
(0.199)\end{array}$ & $\begin{array}{c}-1.185^{* * *} \\
(0.224)\end{array}$ & $\begin{array}{c}-1.007^{* * *} \\
(0.125)\end{array}$ & $\begin{array}{c}-0.463^{* * *} \\
(0.127)\end{array}$ & $\begin{array}{c}-0.967^{* * *} \\
(0.146)\end{array}$ & $\begin{array}{c}-0.713^{* * *} \\
(0.228)\end{array}$ & $\begin{array}{c}-1.026^{* * *} \\
(0.112)\end{array}$ \\
\hline Revenues ex. hydro & $\begin{array}{c}-1.089^{* * *} \\
(0.082)\end{array}$ & $\begin{array}{c}-0.989 * * * \\
(0.165)\end{array}$ & $\begin{array}{c}-1.408^{* * *} \\
(0.147)\end{array}$ & $\begin{array}{c}-1.064^{* * *} \\
(0.139)\end{array}$ & $\begin{array}{c}-0.407^{* * *} \\
(0.069)\end{array}$ & $\begin{array}{c}-1.142^{* * *} \\
(0.153)\end{array}$ & & \\
\hline Population & $\begin{array}{c}-0.002^{* * *} \\
(0.000)\end{array}$ & $\begin{array}{c}0.001^{* *} \\
(0.001)\end{array}$ & $\begin{array}{c}-0.002^{* * *} \\
(0.000)\end{array}$ & $\begin{array}{c}0.001^{* *} \\
(0.001)\end{array}$ & $\begin{array}{c}-0.001^{* * *} \\
(0.000)\end{array}$ & $\begin{array}{c}0.002^{* *} \\
(0.001)\end{array}$ & $\begin{array}{c}-0.002^{* * *} \\
(0.000)\end{array}$ & $\begin{array}{c}-0.001^{* * *} \\
(0.000)\end{array}$ \\
\hline Share pop. sparsely & $\begin{array}{c}8.428^{* * * *} \\
(1.197)\end{array}$ & $\begin{array}{l}-2.934 \\
(5.572)\end{array}$ & $\begin{array}{c}5.759^{* * *} \\
(1.670)\end{array}$ & $\begin{array}{l}-2.388 \\
(6.181)\end{array}$ & $\begin{array}{c}2.693^{* * *} \\
(0.684)\end{array}$ & $\begin{array}{c}4.399 \\
(6.856)\end{array}$ & $\begin{array}{c}4.273^{* * * *} \\
(1.633)\end{array}$ & $\begin{array}{c}5.431^{* * *} \\
(1.770)\end{array}$ \\
\hline Priv. gross income & $\begin{array}{c}0.003^{* * *} \\
(0.001)\end{array}$ & $\begin{array}{c}-0.001^{* *} \\
(0.001)\end{array}$ & $\begin{array}{c}0.002^{* * *} \\
(0.001)\end{array}$ & $\begin{array}{c}-0.002^{* *} \\
(0.001)\end{array}$ & $\begin{array}{c}0.001^{* * * *} \\
(0.000)\end{array}$ & $\begin{array}{c}-0.002^{* *} \\
(0.001)\end{array}$ & $\begin{array}{c}0.003^{* * *} \\
(0.000)\end{array}$ & $\begin{array}{c}0.002^{* * *} \\
(0.001)\end{array}$ \\
\hline Voter turnout & $\begin{array}{c}-0.119^{* *} \\
(0.059)\end{array}$ & $\begin{array}{c}-0.154^{* * *} \\
(0.043)\end{array}$ & $\begin{array}{c}-0.166^{* * *} \\
(0.064)\end{array}$ & $\begin{array}{c}-0.122^{* * *} \\
(0.043)\end{array}$ & $\begin{array}{c}-0.170^{* * *} \\
(0.039)\end{array}$ & $\begin{array}{c}-0.153^{* * *} \\
(0.041)\end{array}$ & $\begin{array}{c}-0.157^{* *} \\
(0.064)\end{array}$ & $\begin{array}{c}-0.135^{* * *} \\
(0.042)\end{array}$ \\
\hline Coalition & $\begin{array}{l}-0.414 \\
(0.470)\end{array}$ & $\begin{array}{l}0.811^{*} \\
(0.492)\end{array}$ & $\begin{array}{l}-0.038 \\
(0.551)\end{array}$ & $\begin{array}{l}1.304^{* *} \\
(0.527)\end{array}$ & $\begin{array}{c}0.234 \\
(0.256)\end{array}$ & $\begin{array}{l}1.039^{* *} \\
(0.438)\end{array}$ & $\begin{array}{c}0.166 \\
(0.539)\end{array}$ & $\begin{array}{l}1.046^{* *} \\
(0.460)\end{array}$ \\
\hline Temp.dev. & $\begin{array}{c}-2.735^{* * *} \\
(0.753)\end{array}$ & $\begin{array}{c}-1.611^{* * *} \\
(0.575)\end{array}$ & $\begin{array}{c}-2.743^{* * *} \\
(1.041)\end{array}$ & $\begin{array}{c}-1.834^{* * *} \\
(0.608)\end{array}$ & $\begin{array}{c}-2.828^{* * *} \\
(0.470)\end{array}$ & $\begin{array}{c}-2.620^{* * *} \\
(0.638)\end{array}$ & $\begin{array}{c}-1.916^{* *} \\
(0.897)\end{array}$ & $\begin{array}{c}-2.034^{* * *} \\
(0.551)\end{array}$ \\
\hline Precip.dev. & $\begin{array}{c}-0.002^{* *} \\
(0.001)\end{array}$ & $\begin{array}{c}-0.002^{* * *} \\
(0.001)\end{array}$ & $\begin{array}{c}-0.002^{* *} \\
(0.001)\end{array}$ & $\begin{array}{c}-0.003^{* * *} \\
(0.001)\end{array}$ & $\begin{array}{c}-0.003^{* * *} \\
(0.001)\end{array}$ & $\begin{array}{c}-0.004^{* * *} \\
(0.001)\end{array}$ & $\begin{array}{c}-0.002^{* *} \\
(0.001)\end{array}$ & $\begin{array}{c}-0.003^{* * *} \\
(0.001)\end{array}$ \\
\hline d_pop10000 & & & $\begin{array}{c}-4.400 * * * \\
(0.930)\end{array}$ & $\begin{array}{l}-0.034 \\
(0.931)\end{array}$ & & & & \\
\hline Efficiency_1 & & & & & $\begin{array}{c}0.745^{* * *} \\
(0.022)\end{array}$ & $\begin{array}{c}0.267 * * * \\
(0.031)\end{array}$ & & \\
\hline $\operatorname{Tax}$ & & & & & & & $\begin{array}{c}-1.735^{* * *} \\
(0.181)\end{array}$ & $\begin{array}{c}-1.384^{* * * *} \\
(0.146)\end{array}$ \\
\hline Block grants & & & & & & & $\begin{array}{c}-0.966^{* * *} \\
(0.115)\end{array}$ & $\begin{array}{c}-0.882^{* * *} \\
(0.098)\end{array}$ \\
\hline Constant & $\begin{array}{c}162.354^{* * *} \\
(9.601)\end{array}$ & $\begin{array}{c}153.745^{* * *} \\
(7.915)\end{array}$ & $\begin{array}{c}174.504 * * * \\
(14.327)\end{array}$ & $\begin{array}{c}157.017^{* * *} \\
(8.469)\end{array}$ & $\begin{array}{c}83.631^{* * * *} \\
(8.151)\end{array}$ & $\begin{array}{c}142.511^{* * *} \\
(10.206)\end{array}$ & $\begin{array}{c}163.948^{* * *} \\
(12.142)\end{array}$ & $\begin{array}{c}158.855^{* * *} \\
(7.097)\end{array}$ \\
\hline R-squared & 0.343 & & 0.475 & & 0.744 & & 0.503 & \\
\hline $\mathrm{N}$ & 2352 & 2352 & 2576 & 2576 & 2038 & 2038 & 2576 & 2576 \\
\hline Year dummies & YES & YES & YES & YES & YES & YES & YES & YES \\
\hline Clustered st.errors & YES & YES & YES & YES & YES & YES & YES & YES \\
\hline Estimation period & $01-07$ & $01-07$ & 01-07 & $01-07$ & $02-07$ & $02-07$ & $01-07$ & $01-07$ \\
\hline
\end{tabular}




\section{J Alternative efficiency measure regressions}

Table 9: Regressions results with the alternative efficiency measure

\begin{tabular}{|c|c|c|c|}
\hline & (1) & $(2)$ & $(3)$ \\
\hline $\mathrm{E}(\mathrm{A} 2)$ & OLS & OLS & $\mathrm{FE}$ \\
\hline Hydro revenues & $\begin{array}{c}-0.578^{* * *} \\
(0.201)\end{array}$ & $\begin{array}{c}-0.641^{* * *} \\
(0.229)\end{array}$ & $\begin{array}{c}-0.453^{* * *} \\
(0.143)\end{array}$ \\
\hline Revenues ex. hydro & $\begin{array}{c}-0.629^{* * *} \\
(0.123)\end{array}$ & $\begin{array}{c}-0.736^{* * *} \\
(0.134)\end{array}$ & $\begin{array}{c}-0.357^{* *} \\
(0.161)\end{array}$ \\
\hline Population & & $\begin{array}{c}-0.001^{* * *} \\
(0.000)\end{array}$ & $\begin{array}{c}0.002^{* * *} \\
(0.001)\end{array}$ \\
\hline Share pop. sparsely & & $\begin{array}{c}0.412 \\
(1.473)\end{array}$ & $\begin{array}{c}-12.113^{*} \\
(6.184)\end{array}$ \\
\hline Priv. gross income & & $\begin{array}{c}0.002^{* * *} \\
(0.001)\end{array}$ & $\begin{array}{c}-0.002^{* * *} \\
(0.001)\end{array}$ \\
\hline Voter turnout & & $\begin{array}{c}-0.150^{* *} \\
(0.071)\end{array}$ & $\begin{array}{c}-0.129 * * * \\
(0.048)\end{array}$ \\
\hline Coalition & & $\begin{array}{l}-0.278 \\
(0.574)\end{array}$ & $\begin{array}{l}0.899^{*} \\
(0.521)\end{array}$ \\
\hline Temp.dev. & & $\begin{array}{c}-2.448^{* *} \\
(1.034)\end{array}$ & $\begin{array}{l}-1.245^{*} \\
(0.636)\end{array}$ \\
\hline Precip.dev. & & $\begin{array}{l}-0.002 \\
(0.001)\end{array}$ & $\begin{array}{c}-0.002^{* * *} \\
(0.001)\end{array}$ \\
\hline Constant & $\begin{array}{c}114.498 * * * \\
(2.597)\end{array}$ & $\begin{array}{c}153.392^{* * *} \\
(13.862)\end{array}$ & $\begin{array}{c}132.210^{* * * *} \\
(9.018)\end{array}$ \\
\hline R-squared & 0.155 & 0.188 & \\
\hline $\mathrm{N}$ & 2583 & 2576 & 2576 \\
\hline Year dummies & YES & YES & YES \\
\hline Estimation period & 2001-2007 & $2001-2007$ & $2001-2007$ \\
\hline
\end{tabular}

${ }^{*} p<0.10,{ }^{* *} p<0.05,{ }^{* * *} p<0.01$

All t-values are based on standard errors clustered at the local government level. 
Centre for Applied Macro - and Petroleum economics (CAMP)

will bring together economists working on applied macroeconomic issues, with special emphasis on petroleum economics.

BI Norwegian Business School

Centre for Applied Macro - Petroleum economics (CAMP)

N-0442 Oslo

http://www.bi.no/camp 